\title{
الخلافات الأسرية وأثرها على تشتت الانتباه عند الأطفال
}

\author{
إعراد \\ الباحثة/ سهام حسن أسعد حسن زينو
}

\begin{abstract}
تحت إشراف
أ.د/ أكرم فتحي يونس زيدان د/ محمد حسين سعد الدين الحسيني

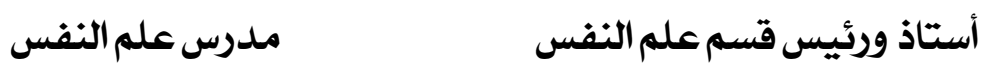

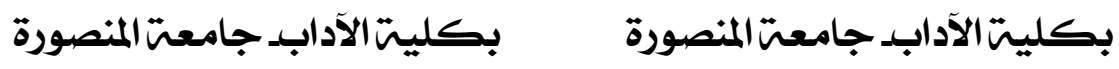

المجلت العلميت لكليتتر رياض الأطفالـ جامعت المنصورة

المجلد الرابع ـ العدد الأول

يوليو r.lv 


\section{الخلافات الأسرية وأثرها على تشتت الانتباه عند الأطفال}

سهام حسن أسعد حسن زينو

\section{مفهوم الخلافات الأسرية:}

عرفت الخلافات الأسرية لغوياً بأنها نز اعات تجـري بــين متعارضـــين لتحقيق حق أو إبطال باطل (معجم اللغة العربية المعاصر).

يعرف كمال مرسي الخلافات الأسرية بأنها تباين فـي أفكـار ومسـشاعر

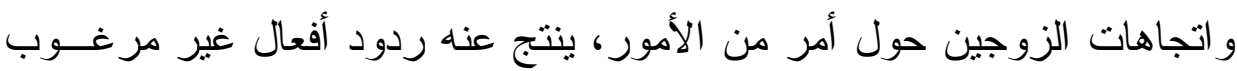

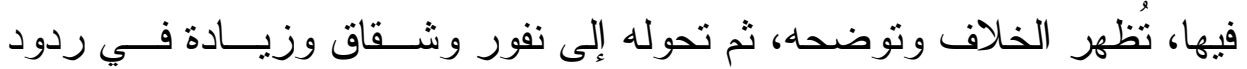

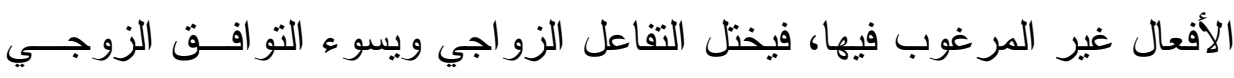

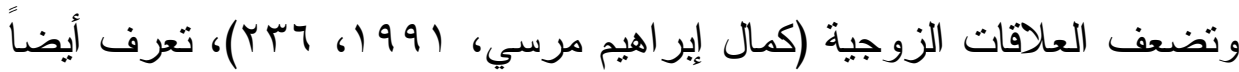

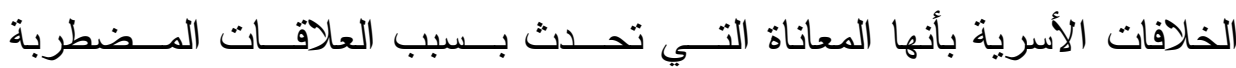
كالتو اصل السيئ، و الجدال الددمر ، و الألم النفسي. (S Cordovan.J\& Jacobson.

(S, 1993, 483

يعرف الدليل التشخيصي و الإحصائي الإصدار الرابع الخلافات الأســرية

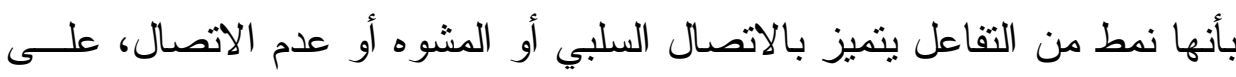

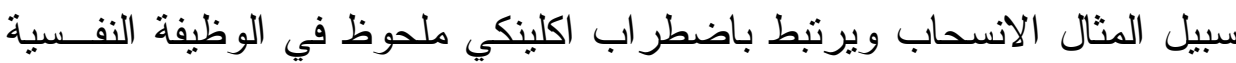

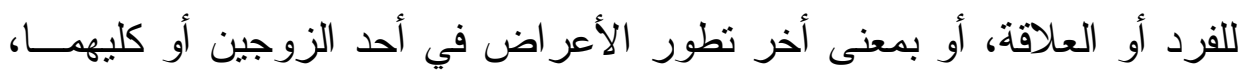

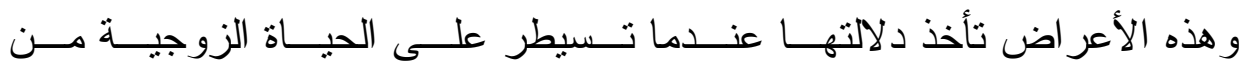

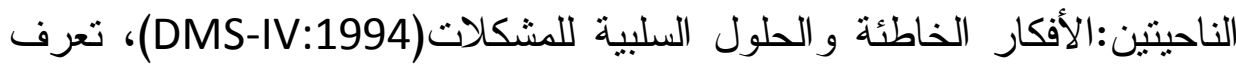

"باحثة 
أيضاً الخلافات الأسرية بأنها تقدير ات منخفضة للسلوك المتبادل، ومهار ات حـل

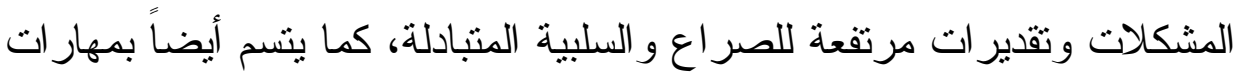
اتصال ضعيفة، وتقدير ات منخفضة للأنشطة الترفيهية المشتركة (بنــون أيسـان،

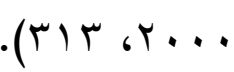

تعرف الخلافات الأسرية أنها بمثابة المعارك التي تشتغل فـي الأســرة،

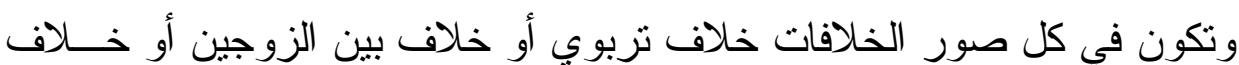

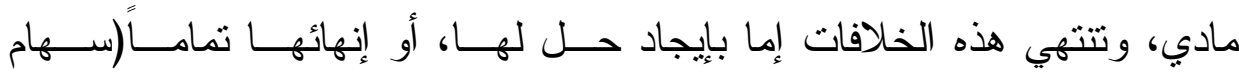

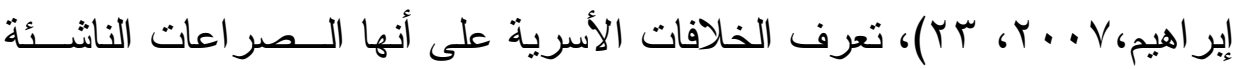
بين الزوجين نتيجة عدم النقارب في السمات الثخصية، أو بـسبب الــشكلات

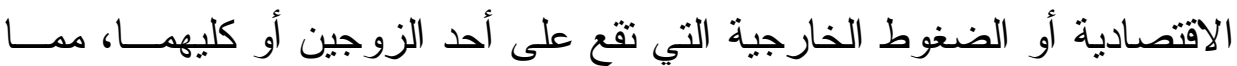

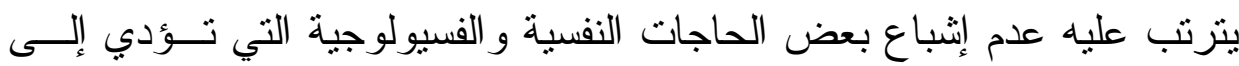

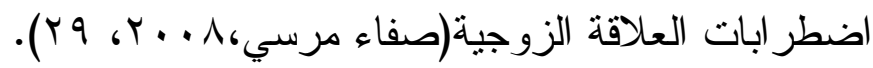

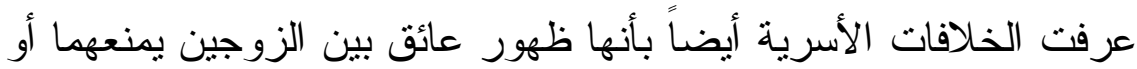

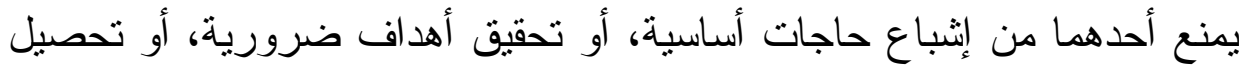

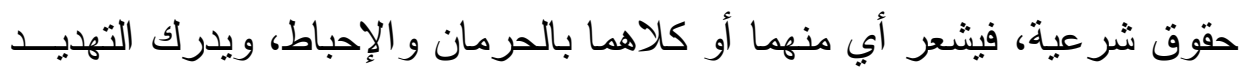

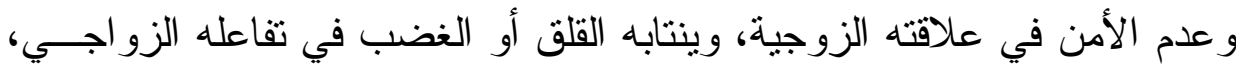

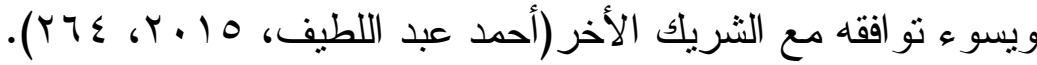
وفقاً لما تم عرضه من تعريفات للخلافات الأسرية فيمكن تعريفها إجر ائياً

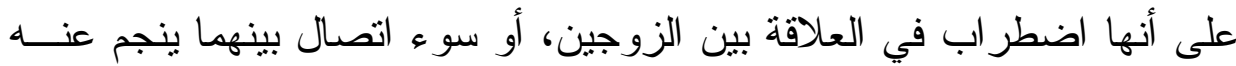

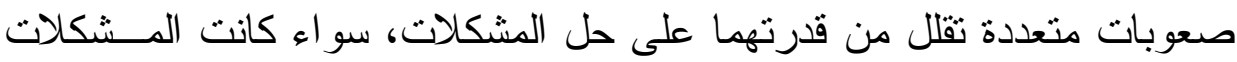
مالية أو مشكلات تخص الأبناء، و غير ها من المشكلات التي تخلق معاناة نفـسية قد تؤدي في النهاية إلى الطلاق. 


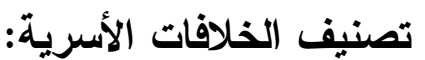

تتقسم الخلافات الأسرية بحسب تأثثير ها على التفاعل الزو اجسي و التو افـق

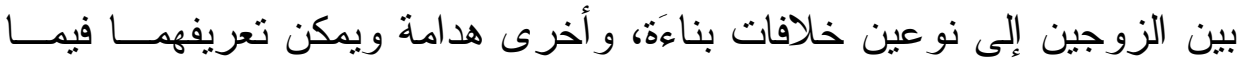

أولاً: الخلافات البناءَة: هى خلافات لا تفسد الود بين الزوجين، و لا تؤدي إلـى

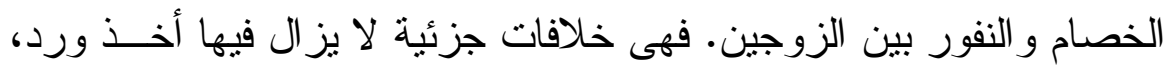

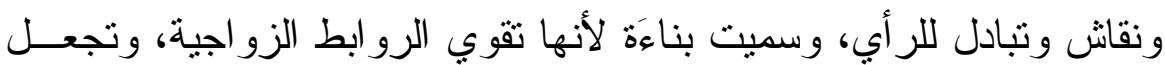

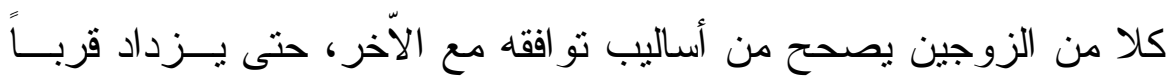

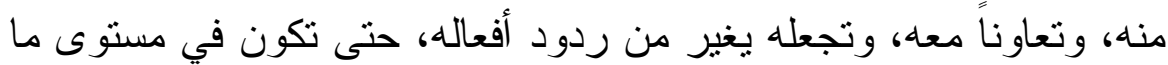

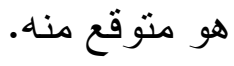

ثانياً: الخلافات الهدامة: يقصد بها الخلافات التي تؤدي إلى الخــــام و العــداوة

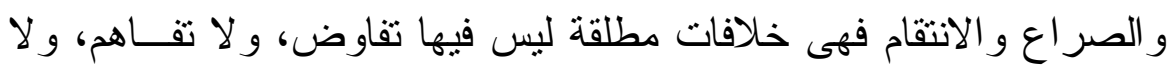

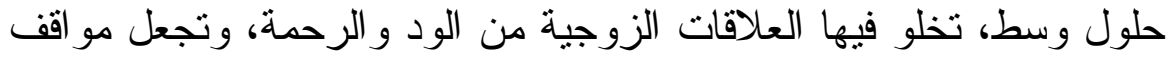

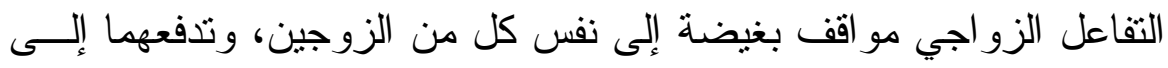
النو افق الزو اجي السيء، وتتبيء بهدم العلاقة الزوجية ووقوع الطلاق(كمال

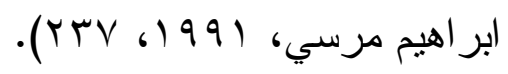
كما صنف أحمد الكندري الخلافات الأسرية إلى ثلاث فئات هي: 1-التمزق أو فقدان أحد أفراد الأسرة ويعني بالتمزق فقد أحد أعضاء الأسرة

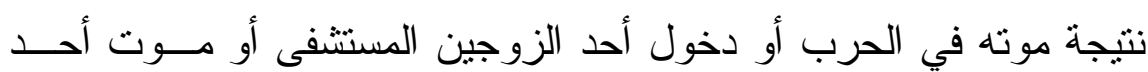

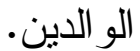




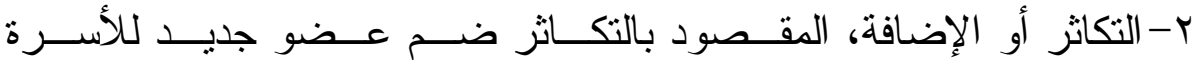

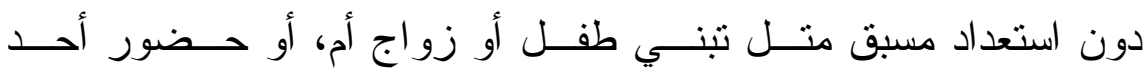

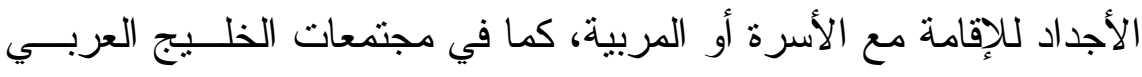
حالياً. ب-الانهيار الخلقي: فيشير إلى فقدان الوحدة الأسرية و الأخلاقية، ويقصد بــه

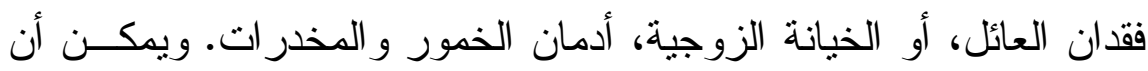

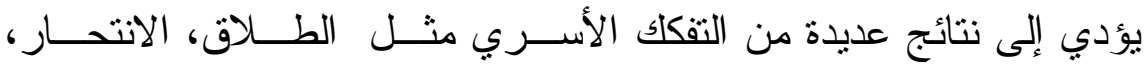

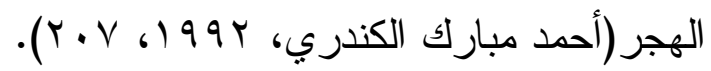

\section{في حين قَسم محمد الجوهري الخلافات الأسرية إلى:}

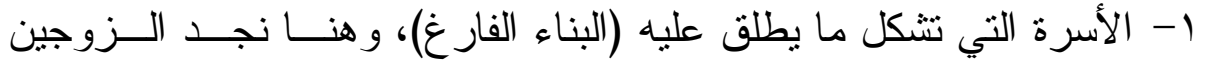

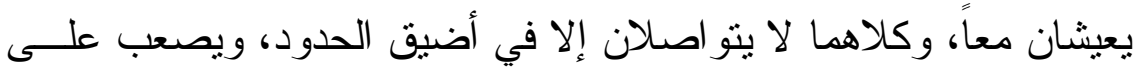
كل منهما منح الآخر دعماً عاطفياً.

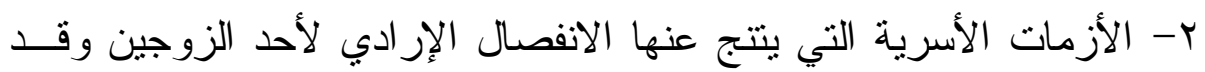

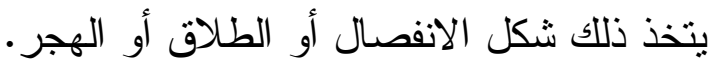

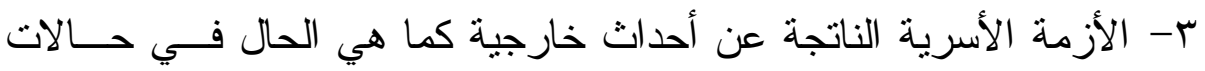

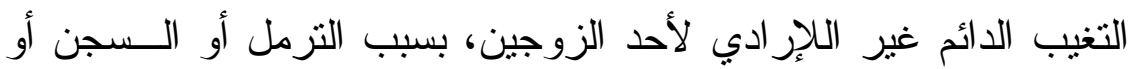

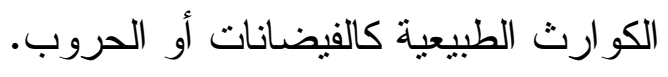

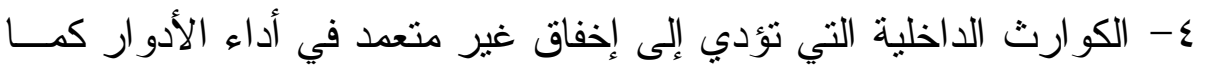

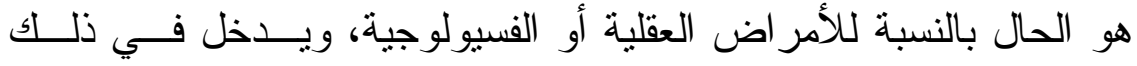

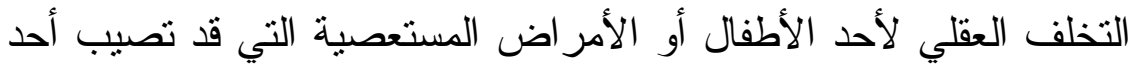

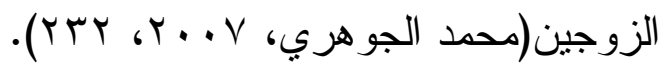




\section{و أيضا صنف عبد الخالق عفيفي الخلافات الاسرية إلى:}

المستوى الأول: ويشمل الخلافات البسيطة التي تحدث بين الزوجين، ولا

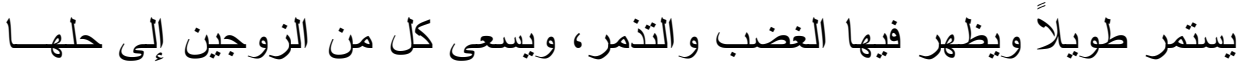

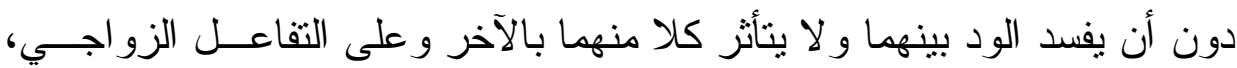
حيث يظل المناخ النفسي و العاطفي في الأسرة جيداً.

المستوى الثاني: وقد تثتند النزاعات بين الزوجين وتشتمر لـدة طويلــــة

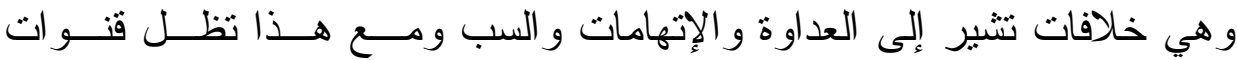

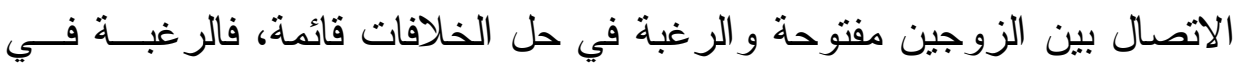
استمر ار عند هذا المستوى من الخلاف ماز الت قائمة. المستوي الثالث: وتشتمر فيه الخلافات مدة تزيد عن ستة أثنــهر تــؤدي

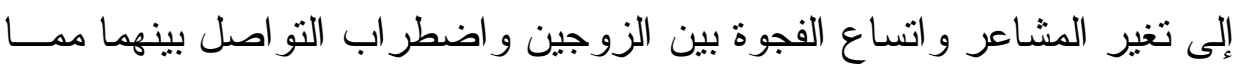

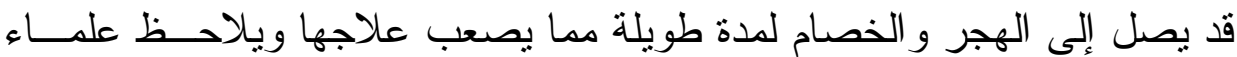

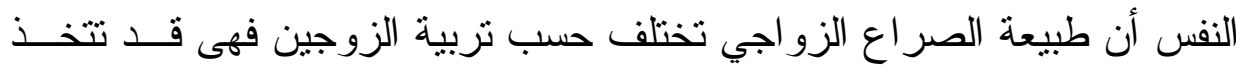

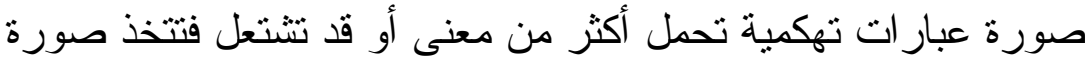

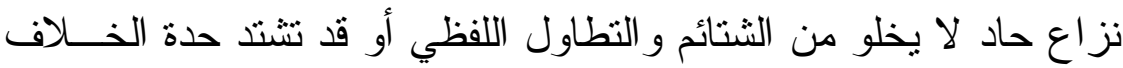

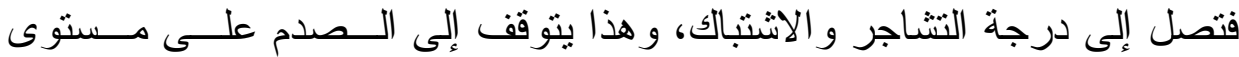
الطبقات الاجتماعية الني ينتمي إلىها كل من الزورج و الزوجة (عبد الخالق محمد التها

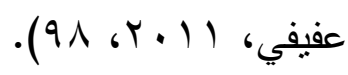

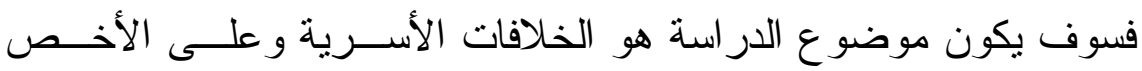
الخلافات الهـامة التي وصلت إلى إنهاء الحياة الزوجية بين الــزوجين وقـــرورا

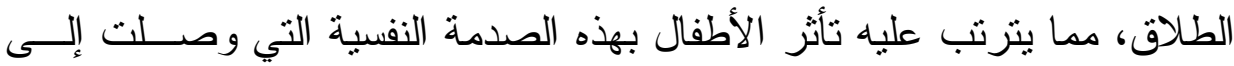


حدوث اضطر ابات الانتباه لدى الأطفال وتأخر النمو اللغوي بعد حدوث الطلاق،

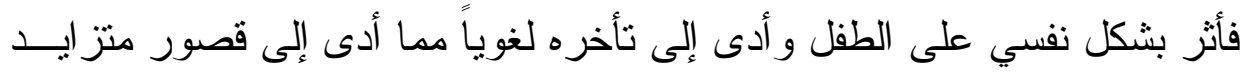

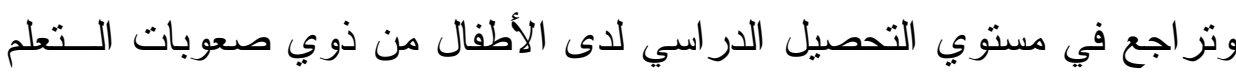

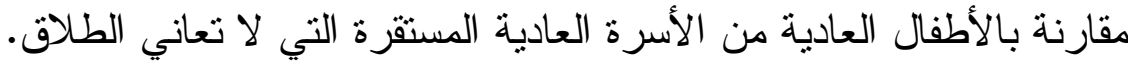

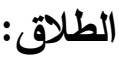

الطلاق ظاهرة اجتماعية دولية تؤرق الكثير مـن المجتمعسات و الأسـر،

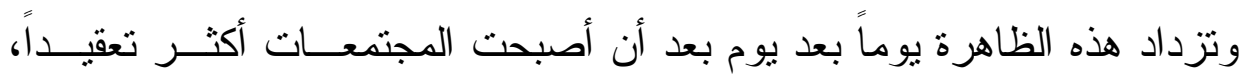

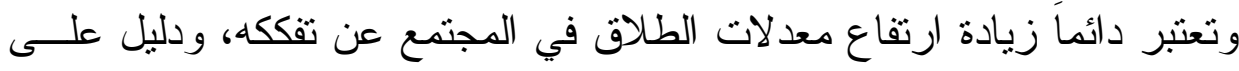
التغير في نسق الأسرة، وبذلك يصبح مؤشر أ على التغير في بناء المجتمع ككل. وبعد الإحصائيات التي اتضح منها ارتفاع مشكلة الطلاق ويعتبر الطــلاق

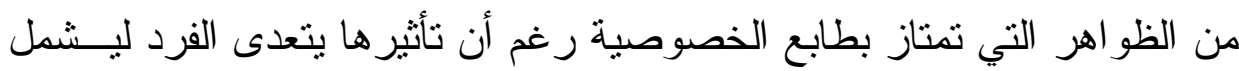

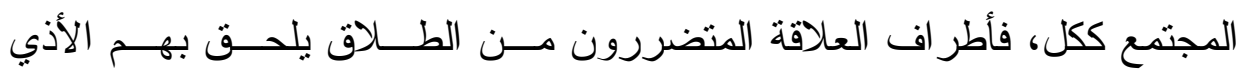

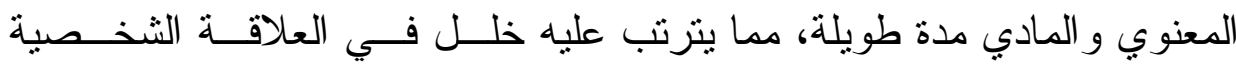

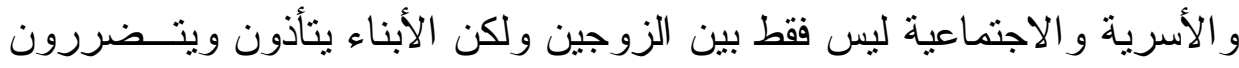
نفسياً وسلوكياً بسبب الطلاق.

فإن دور الأباء و الأمهات لا يتقصر على توفير المال والطعام والمسكن لئن و الملبس لأبنائهم بل يمتد لتوفير الحب و الحنان و الرعاية النفسية التي لا يجـدون لها بديلاً عند أي فرد آخر بعد أن يعزم الأبوين على اتخاذ خطوة الطلاق. مما يترتب عليه أثنار وأخطار تصيب شخصية الأبناء كالاضطر اب و القلق و التوتز و الحزن و الاكتئاب و عدم تقدير الذات و غيرها من المشاكل النفسية، غير

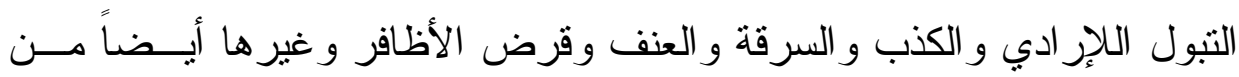

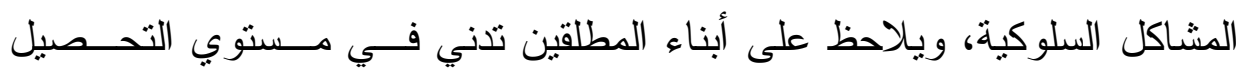


الدراسي النتائج عن عدم تركيز هم وتتنتهم الدائم في الفصل، وما يصيبهم مـن

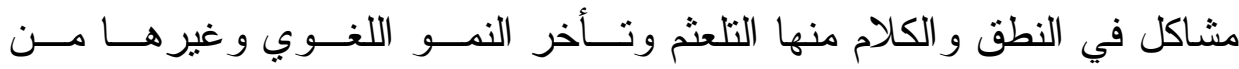

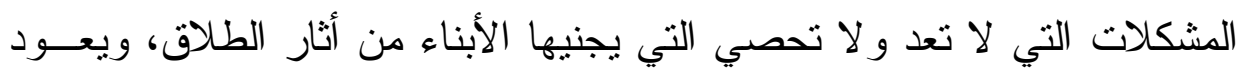

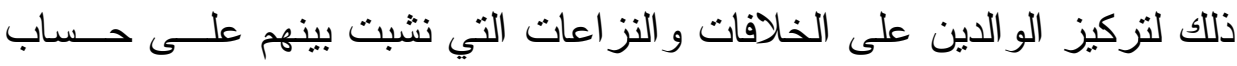

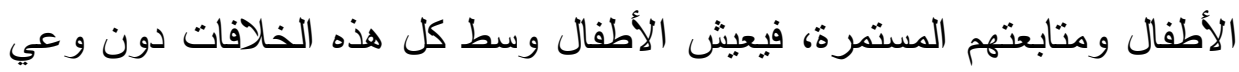

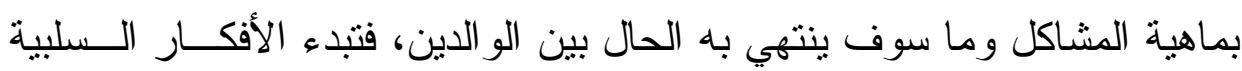

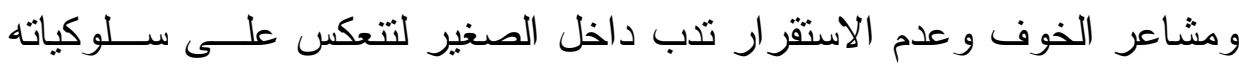

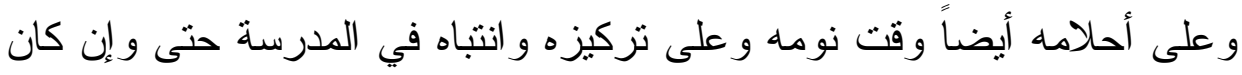

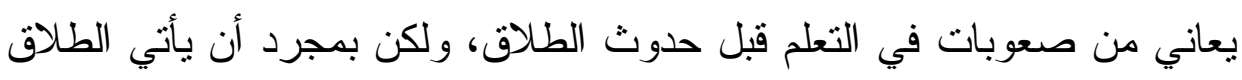
تتفاقم المشكلة لديه وتتصاعد.

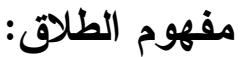

الطلاق من المنظور اللغويهو حل العقد، سواء كان حسياً كقيد الفرس وقيد

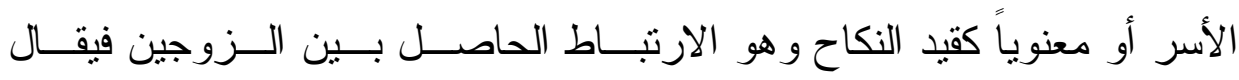

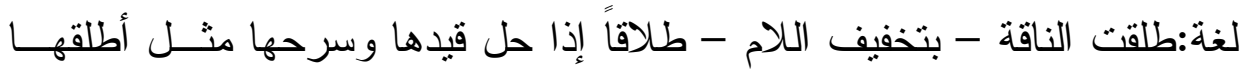

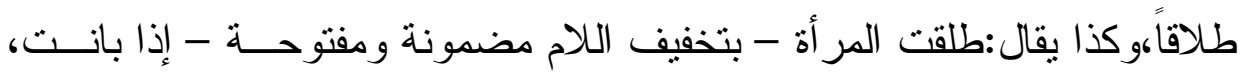

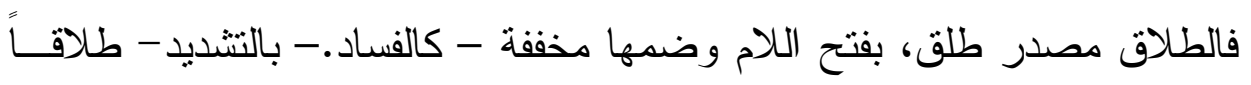

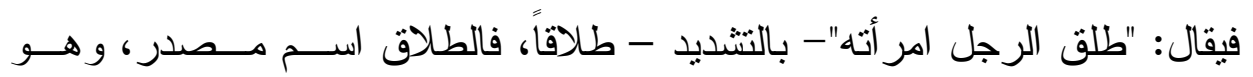

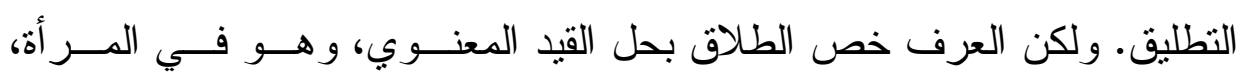

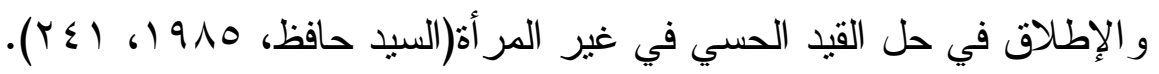
في حين يعرف ابن منظور بالفتح نطلق طلاقا. أطلق الناقة من عقالهــا.

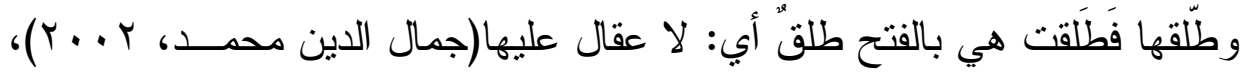

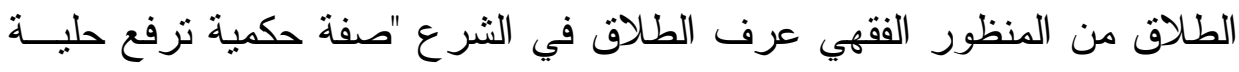




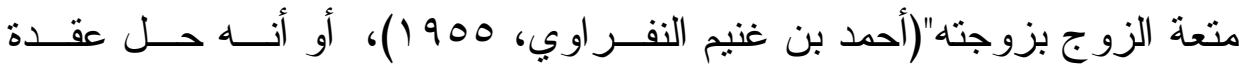

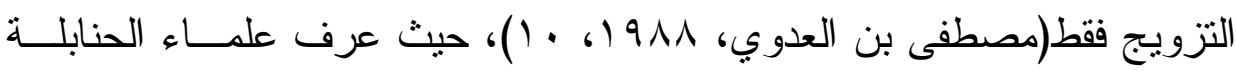

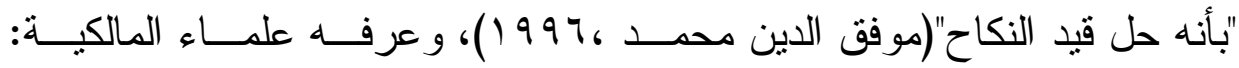

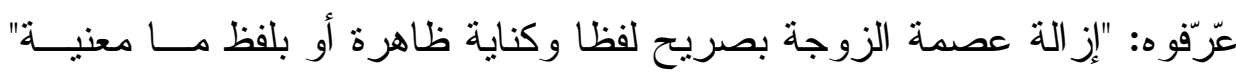

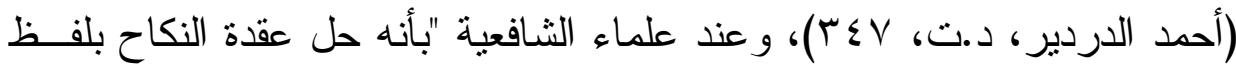

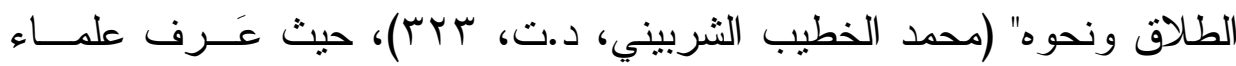

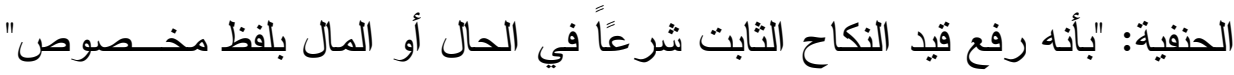

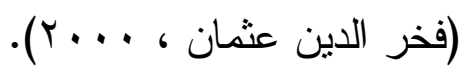

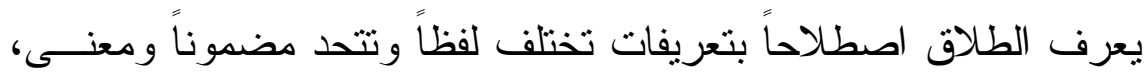

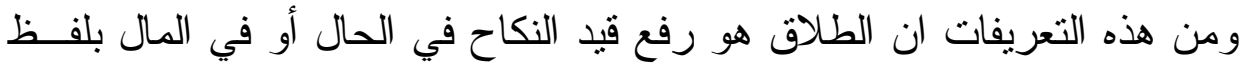

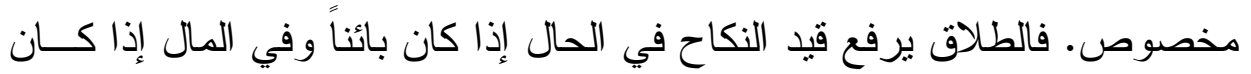

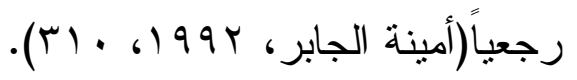

ويعرف الطلاق في المنظور القانوني: من وجهة نظر قــانون الأحسـوال

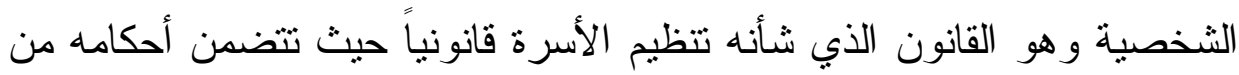

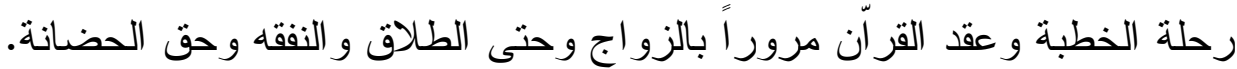

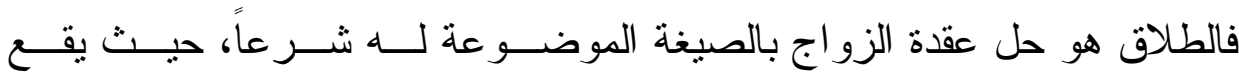

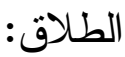
أ. باللفظ الصريح، أو الكتابة، وعند العجز عنهما، بالأشارة المفهومة. ب.بالكتابة إذا نوى الزوج إيقاع الطلاق. ويشترط في المطلق:

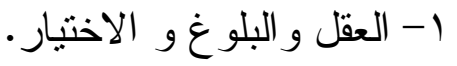




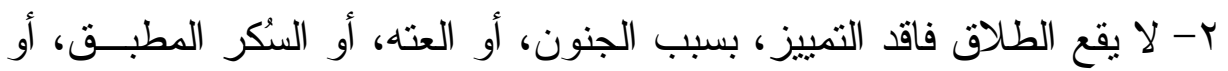
الإكر اه الملجيء أو غير ذلك من الأسباب المذهبة للعقل.

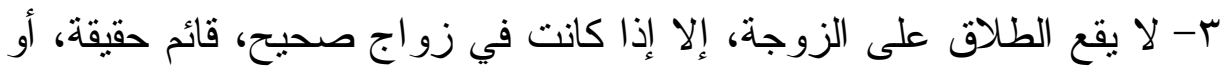
حكماً.

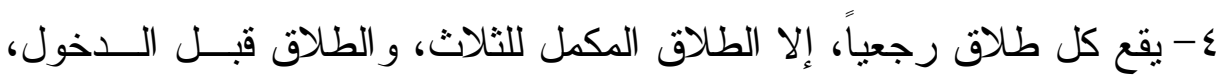

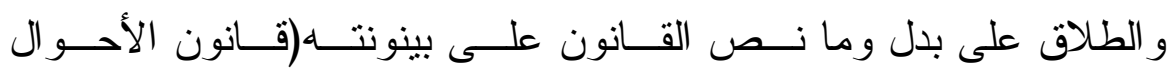

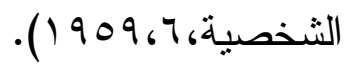

\section{الطلاق في المنظور الاجتماعي:} تتوعت النظريات الاجتماعية لتفسير الطلاق منها ما يلي:

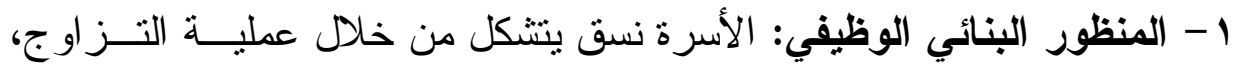

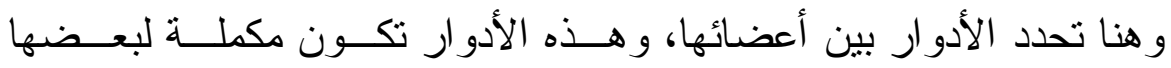

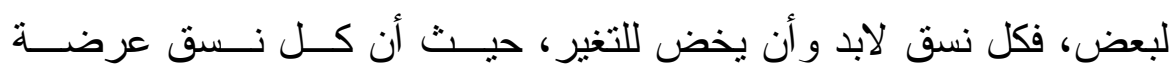

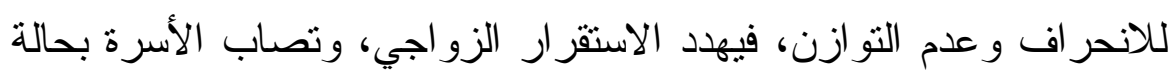

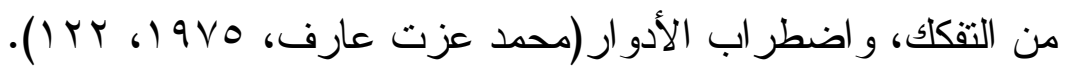

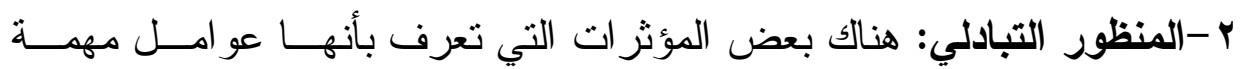

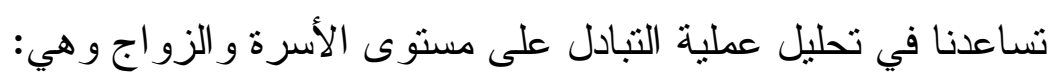
• التوجهات المعيارية: تعني توقعات الزوجين للزوو اج كمؤسسة اجتماعية،

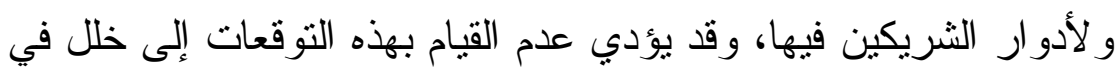
نظام الأسرة بنتهي بالطلاق.

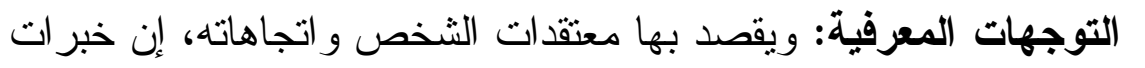
الفرد خلال عملية التتشئة الاجتماعية لها أثار هامة على الكيفية التي يبدأ بها الزوجين و علاقتهما. 


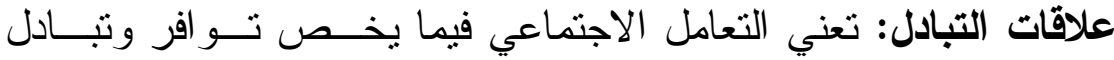

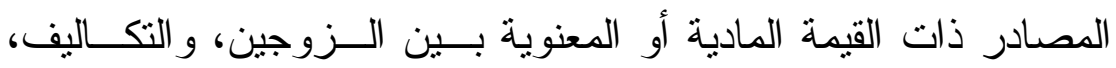

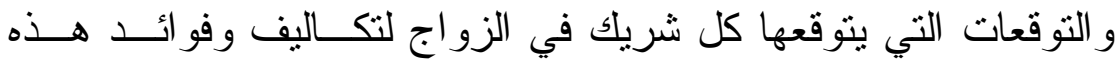

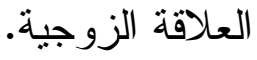

دايمومة الزواج: تنظر أغلب المجتمعات إلى الزاوج على أنــــه علاقـــة

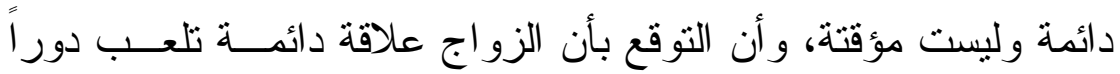

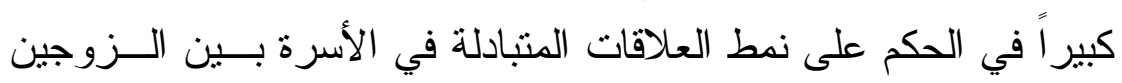

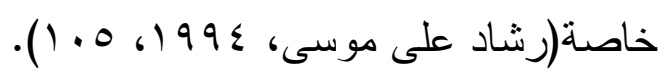

r- المنظور الصراعي: قد تبين أن أي وضع اجتماعي يصبح مشكلة اجتماعية

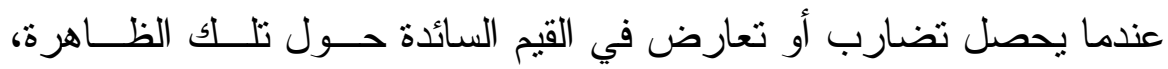

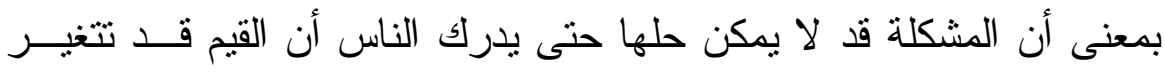

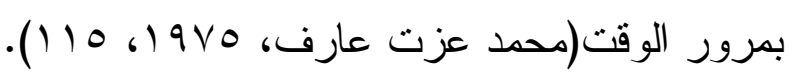

ع - المنظور اللامعياري: هو الاتجاه النظري لــ " إميل دور كايم" في تقـسيره

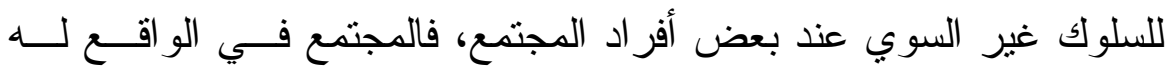

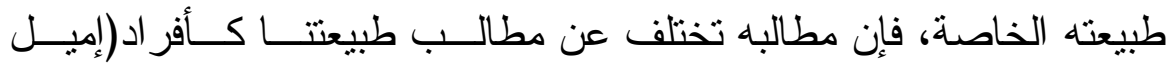

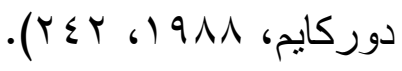

ه - منظور تماسك الأسرة: هناك عو امل تماسك و انحلال العلاقة بين الزوجين

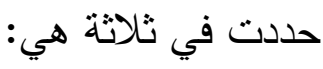
1- إثباع احتياجات الزوجين المعيشية و الأمنية والحب و الاحتر ام و العشرة و التنتع الجنسي.

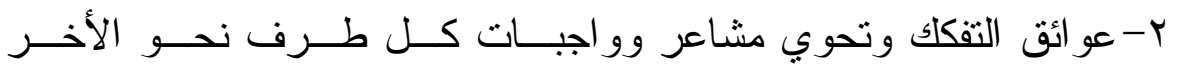
ومسئولياتهما تجاه أطفالهما. 
r- العو امل المنافسة مادية كالاستقلال الاقتصـادي للفرد أو رمزية كتحقيـق

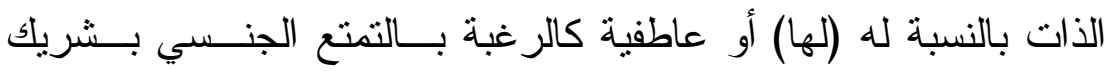

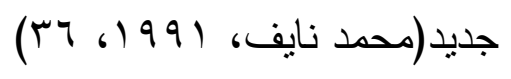

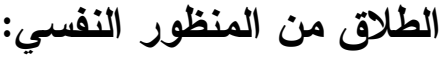

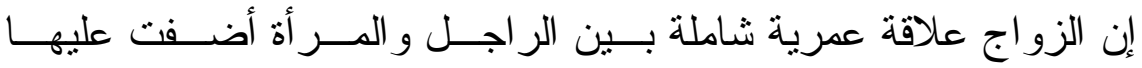

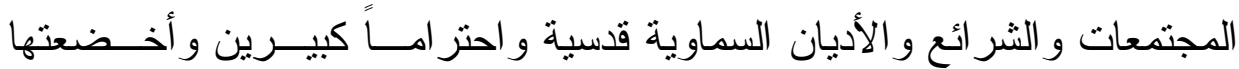

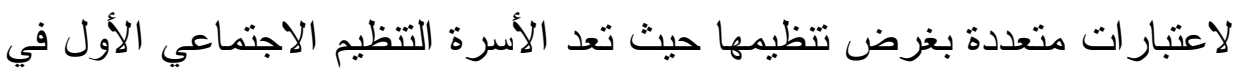

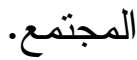

لقد عرف الإنسان ومارس العديد من العلاقات العاطفية و الجنسية خــارج

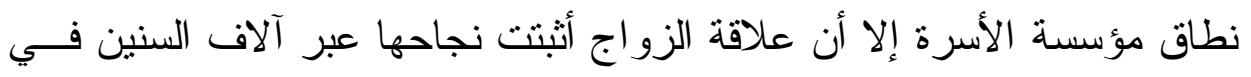

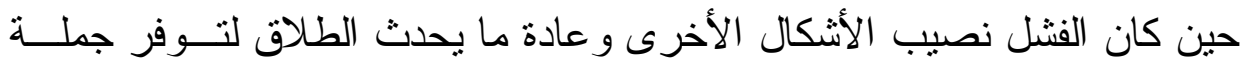

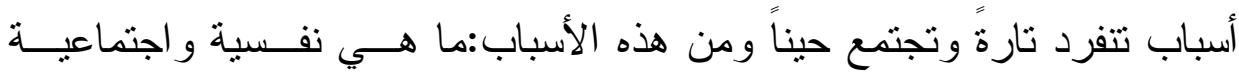
و اقتصادية ودينية ....

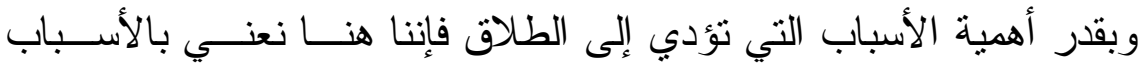

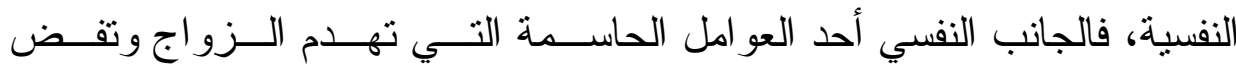
مضجع الأسرة و إذا نظرنا للموضوع من زائب الفية علم النفس فسنتاوله على النحو الآتي :

$$
\begin{aligned}
& \text { 1- 1- 1الثخصية. } \\
& \text { r- ب- السلوك الجنسي. } \\
& \text { r- الصحة النفسية (سناء سليمان، r ؟ • r، 9 ؟). }
\end{aligned}
$$




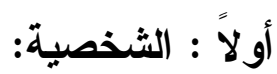

تعتبر الثخصية أحدى موضوعات علم النفس التي نالت اهتماماً متز ايــداً

بسبب طبيعة خصائصها (الميول، الاتجاهات، الدو افع، الانفعالات ) ويقصد بالثخصية تلك الأنماط المستمرة و الدتسقة نسسبياً مــن الإدر الك

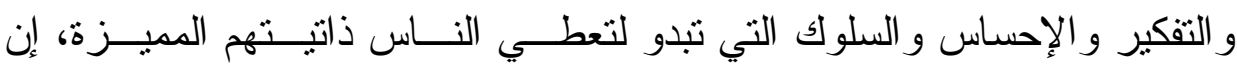

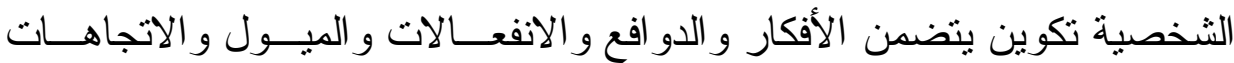

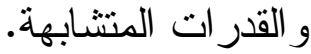

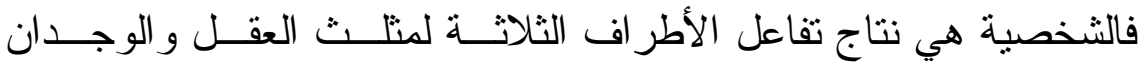

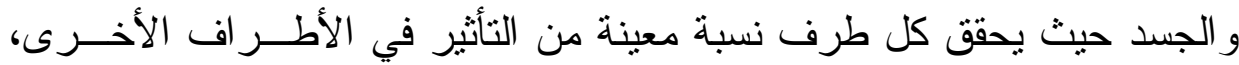
ويتبين مما تقدم أن طبيعة الثخصية وما يترنب عليها من أنماط سلوكية متعـددة على جانب كبير من الأهمية في تحقيق الانسجام بين الـــريكين وبمـــا يـــنح الأسرة ومنظومة علاقتها التوازن و الاستمر ارية غير إن النفس شأنها شأن الجسد

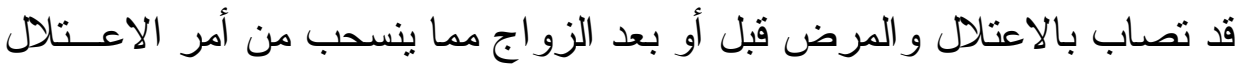
و المرض على جسد العلاقة فيدفعها للاختلال ثم الانفصال.

إن وعى أحد الثريكين أو كلاهما بهذه الاعتلالات سيمكنها من الـسيطرة عليها وذللك بالاستعانة بخبرة الطبيب المختص أو الاخصائي النفسي ومن أنماط

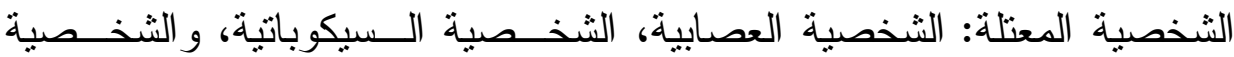
الفصامية، ونتيجة لهذه الاعتلالات يفشل الأزواج في تقليل الاختلاف في عادات

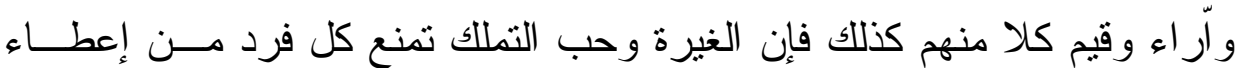

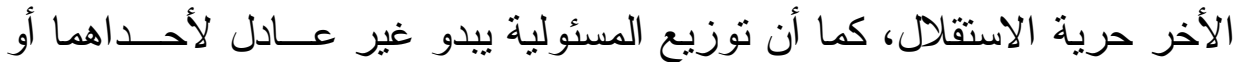

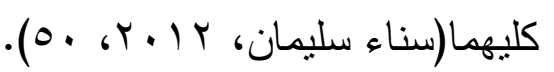


ثانياً: السلوك الجنسي :

يعتبر الدافع الجنسي عند الإنسان من الدوافع الأساسية المهــــة، فعـلاوة على كونه حاجة بيولوجية بضمن للجنس البشري بقائه إلا أنه بمنل حاجة نفسية تقدم للإنسان المتعة وتخفف عنه التونز و المعاناة.

إن ممارسة السلوك الجنسي بشكل سوي يعبر عـنـ النــضوج الجنـسي

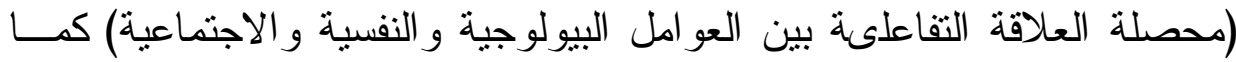
يعتبر مؤشر اً طبياً لصحة الإنسان النفسية. - العوامل المؤثرة في السلوك الجنسي: 1-نقص المعرفة الجنسية. r-الاضطر ابات الجنسية عند الرجل / المر أة.

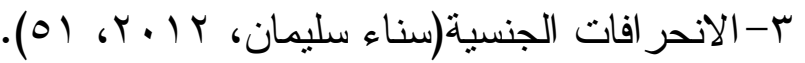

ثالثاً: الصحة (النفسية:

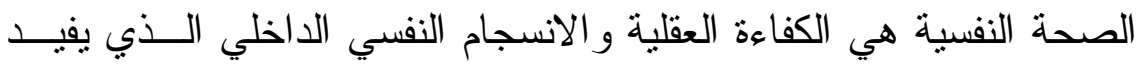

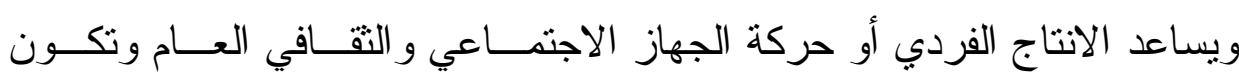
مصحوبة عادة بشعور من السعادة و الارثياح. فالصحة النفسية السوية من شأنها أن تهيهيء لكلا الطــرفين بيأــة تتـسم

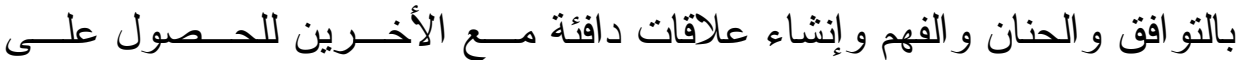
الإشباع وتحقيق الذات و على النقيض من ذلك حالة اللاسو اء أو الاعتدال الــذي الــي

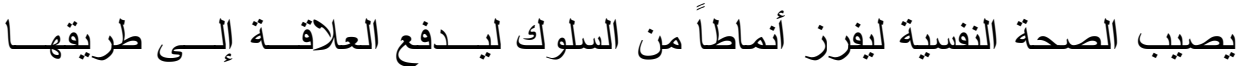

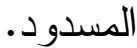




\section{ومن جملة الاعتلالات النفسية التي تصيب الفرد:}

(القلق - الاكتئاب - الهستيريا - المخاوف المرضية - الأفكار التسلطية

- الوساوس المرضية - الزهو - الفصام وغيرها من الأمر اض و الاعتلالات -

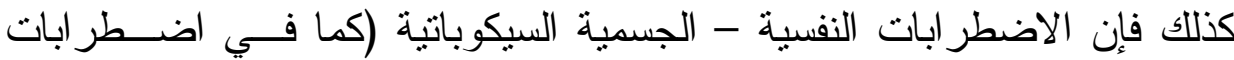

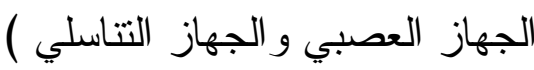

تلعب درواً في إثثاعة جو من السوداوية و القنوط ليحيل أجــو اء العلاقــة الزوجية إلى ساحة من فقدان الرجاء و الانهز امية، وتتو إلى أنماط مسـن الـسلوك

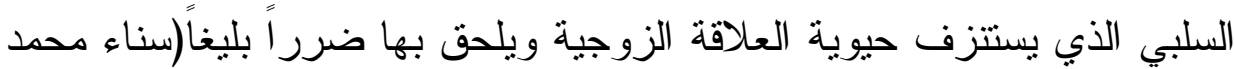

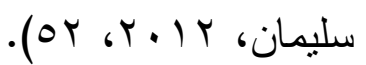

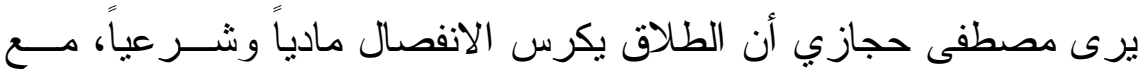

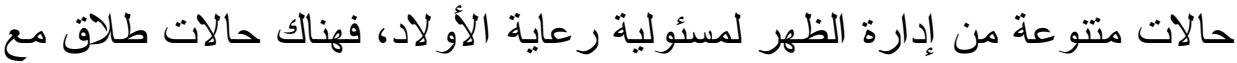

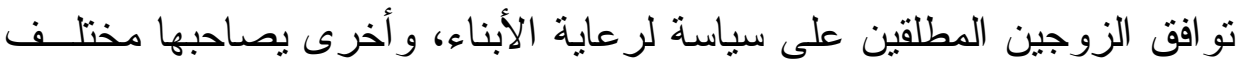
ألو ان الإهمال و النسيب و النبذ وحرمان الزوجة و أبنائها من حقوقهم. و أنه انطفاء الزياء

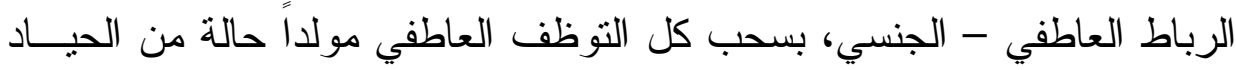
و التباعد تجاه الأخر • وفي حالات آخرى يحدث التباعد بعد فنرة من المجابهـات و المناز عات تطول أو تقصر يحدث فيها نوظيف مضاد للعدو انية تجــاه الآخــر و الحرب عليه، ومحاولة إنز ال أكبر الأذى به. أما طاقة الحب التي تم ســــانها،

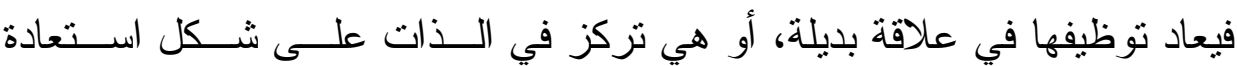

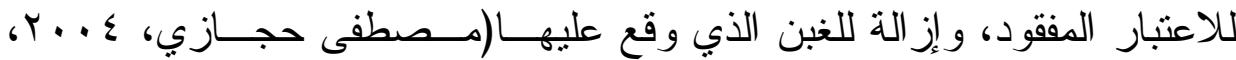




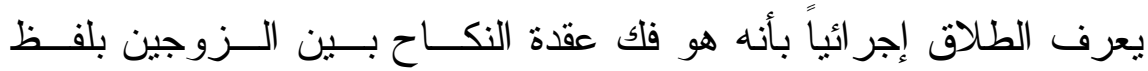

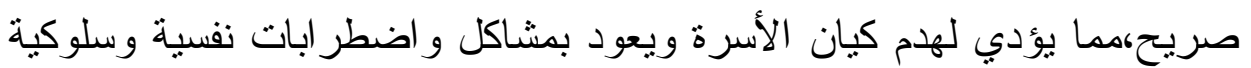
ولغوية ومعرفية عند الأبناء.

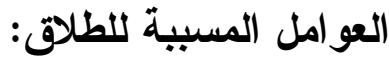

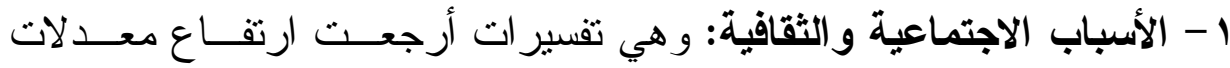

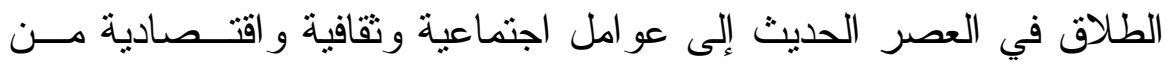

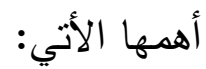

أ. تعقد الحياة الصناعية، وما ترتب عليها من ضعف في الرو ابط الأســرية

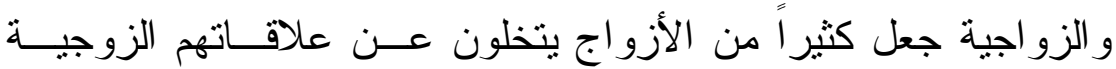
بسهولة.

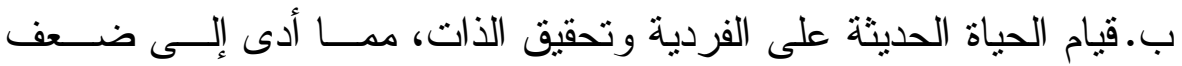
الغيرة و التضحية، و التي تقوم عليها الحياة الزو اجية بالأسرة.

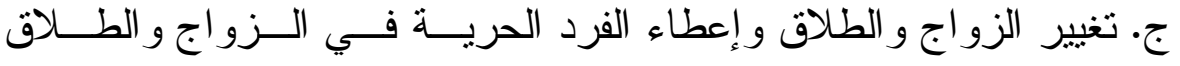

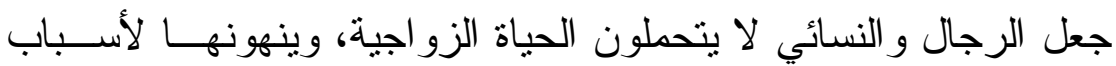
بسيطة. د. الأزمات الاقتصادية و السياسية والاجتماعية سالتـي تو اجهرـــا الأســرة

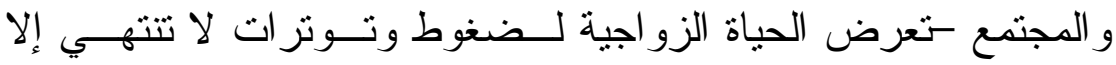
بالطلاق. ه. سوء الاختيار في الزواج، ووجود تباين كبير بين الزوجين فــي الــسن

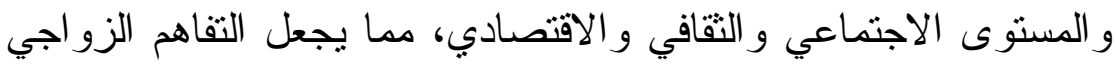

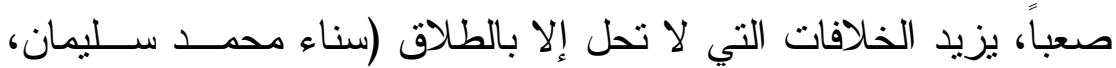
. (Or, r. tr 


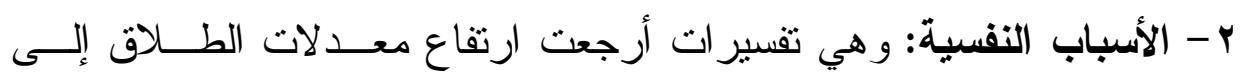

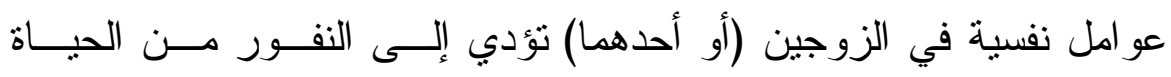
الزوجية، وتوصلهما إلى الطلاق، من هذه التفسير ات الأتية:

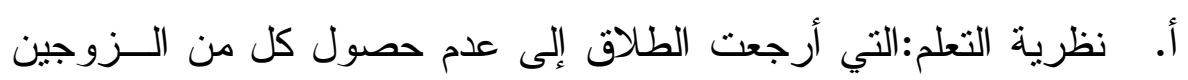

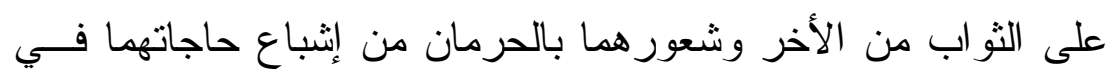

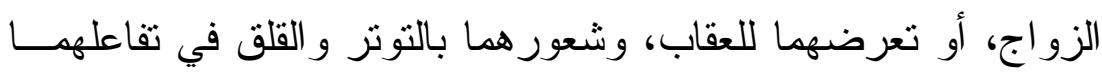

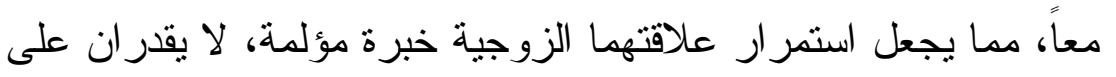
تحملها ويكون الطلاق وسيلة لتخليصهما من مشاعر الحرمان، و التوتز

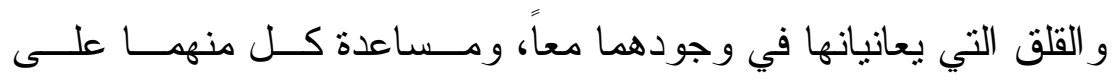

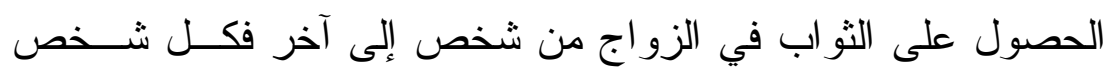

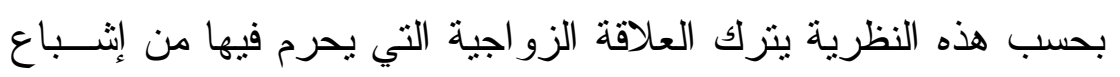

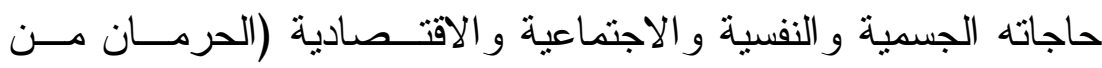

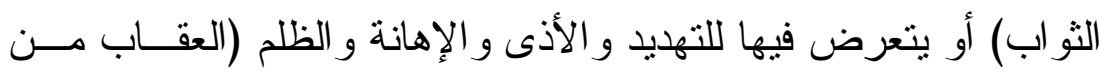
الزواج الاخر).

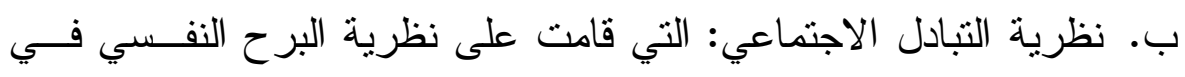

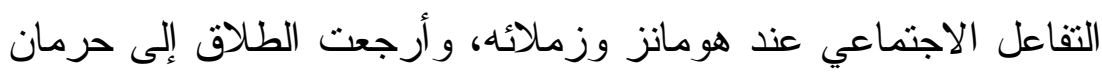

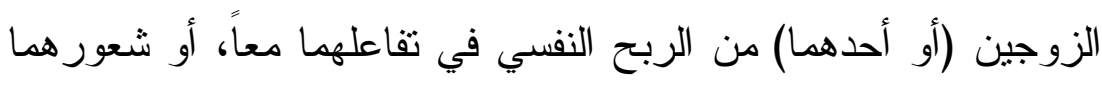

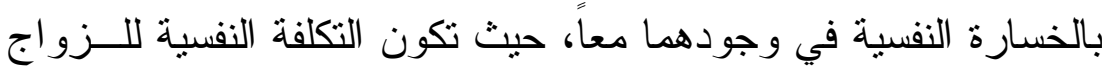
أكبر من العائد النفسي. فكل شخص ودئ بحسب هذه النظرية سيترك العلاقة

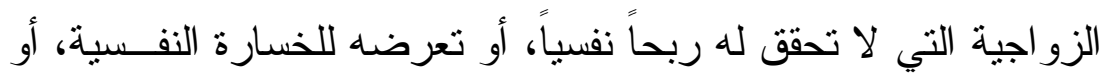

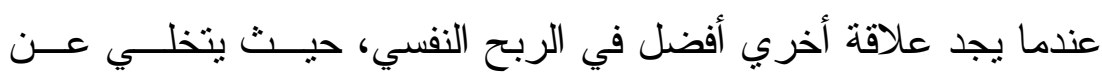

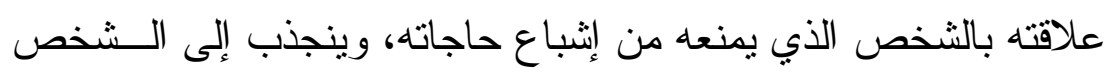


الذي يجد في تقاعله معاً ما يرضي حاجاته(مصطفى حجــازي، ـ. . ؟،

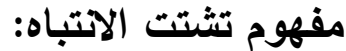

تعريف تشتت الانتباه اصطلاحي هو اضطر اب عصبي سلوكي ناتج عـن

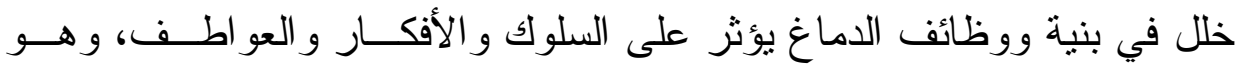
اضطر اب بمكن التعامل معه وتخفيف حدة أعر اضه بهدف مساعدة الطفل علـى لـى (Carsini, 1999). التعلم وضبط النفس مما يساهم في رفع مستوى تقته بنفسهاه

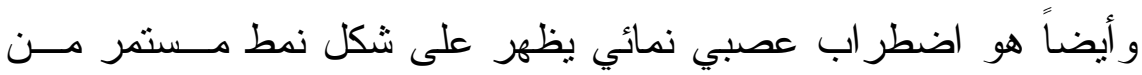

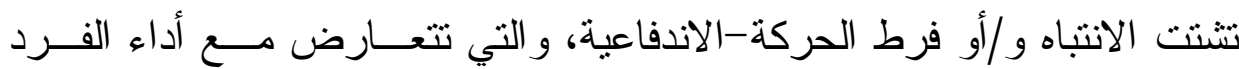

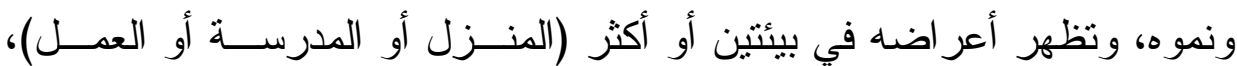

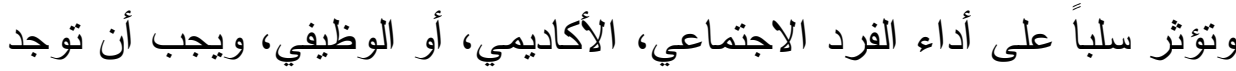

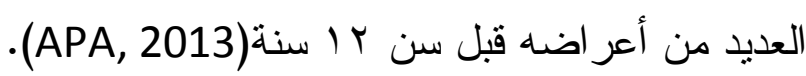

وهو أيضاً اضطر اب يحدث فيه ميل الطفل إلى النشاط الحركي الدفـرط

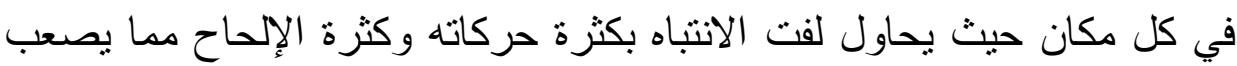

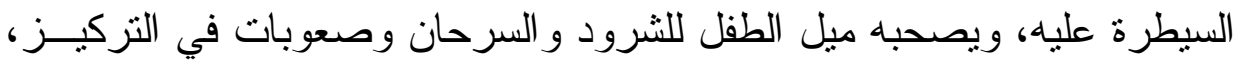

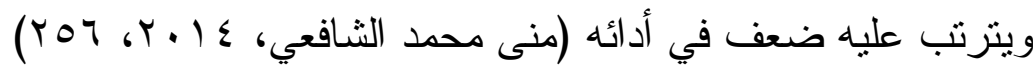

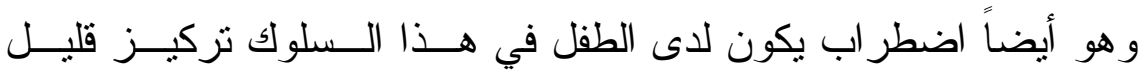

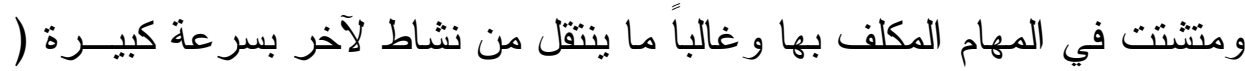

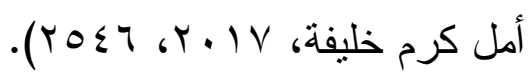

يعرف تشتت الانتباه إجر ائياً بأنه اضطر اب عصبي ســلوكي يتـسم فيــهـ

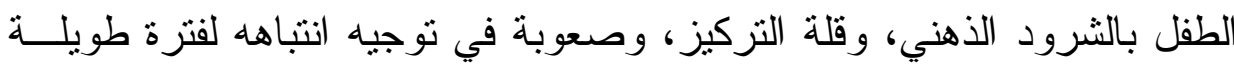


في نشاط معين، مما يؤدي إلى ضعف في مستوى التحــصيل الدراســي لليــهـ

$$
\text { وصعوبة في التعلم. }
$$

العوامل أو الأسباب التي تؤدي إلى تثتت الاتتباه:

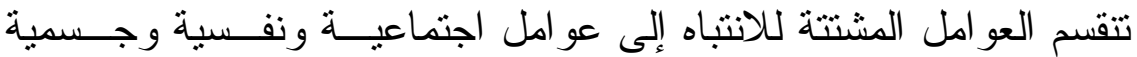

$$
\text { وفيزيقية وهي كما يلي: }
$$

1- العوامل الاجتماعية: هنالك عدد من العوامل الاجتماعية التي تــؤدي إلـى

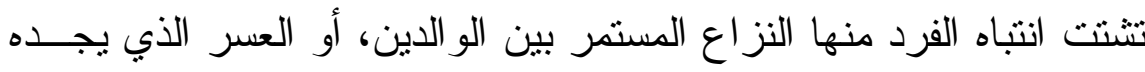

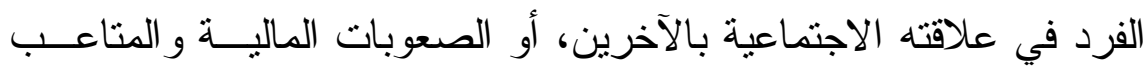

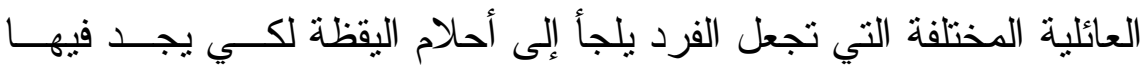

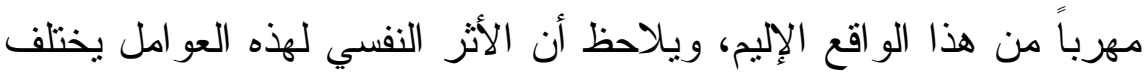
باختلاف قدرة الناس على التحمل و الصمود.

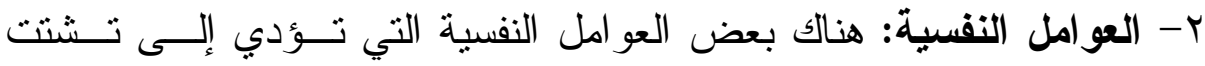
الانتباه متل عدم ميل الطالب إلى مادة معينة، وهذا يؤدي إلى عدم اهتمامه

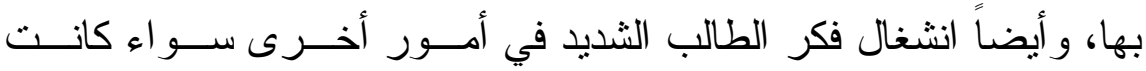

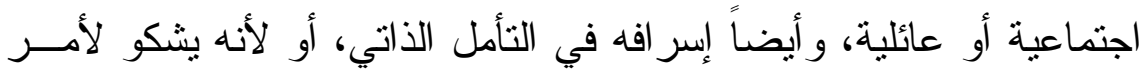

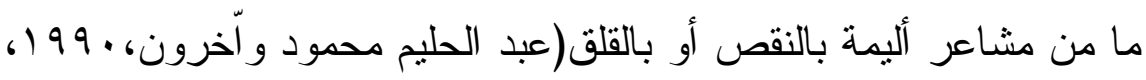
.(1)

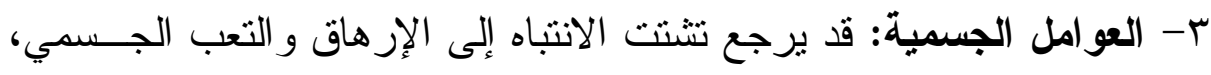

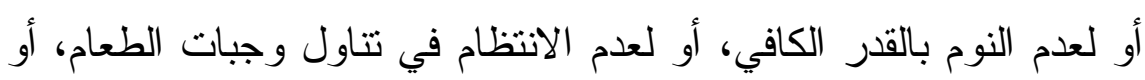

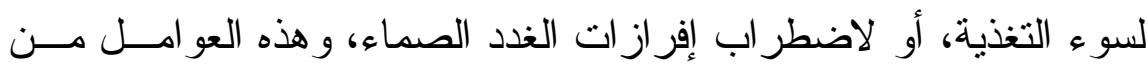

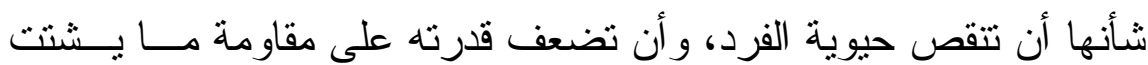
انتباهه. 
ع- العوامل الفيزيقية: أن من أهم العوامل الفيزيقية التي تؤدي إلـى تـشتت

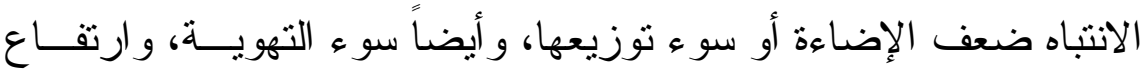

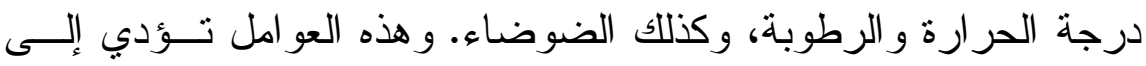

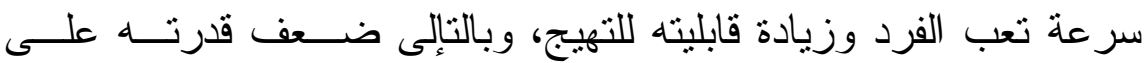

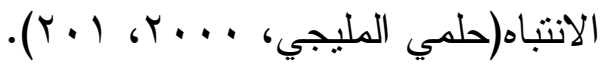

فهناك أسباب داخلية وأسباب خارجية تؤثر على الانتباه:

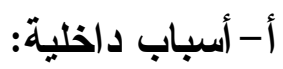

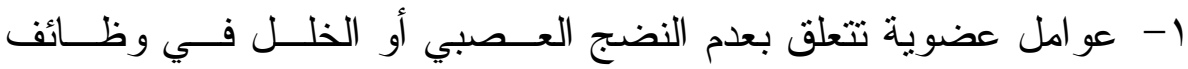
المعرفية و الانفعالية للنصفين الكروبين بالمخ بهن.

r- ضعف في قدرة الطفل على تمييز العلاقات بين الثكل و الخلفية بـسبب ضعف المهار ات الإدر اكية عنده.

ب- عدم قدرة في الطفل على إدر الك التسلسل مما يؤثر على الإصغاء حيــث

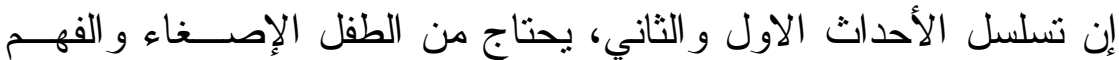
و التذكر ثم القيام بالعمل المناسب.

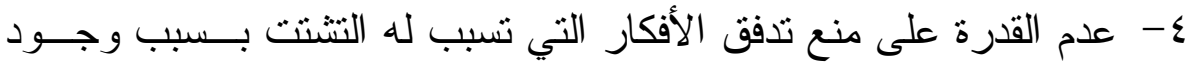

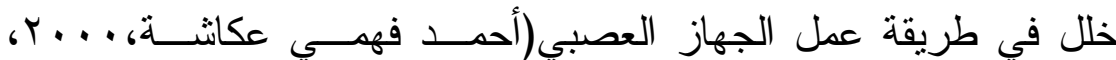
. (r. TO

\section{ب - أسباب خارجية:}

و هي أما تساعد على إخفاء الصعوبة أو إظهار ها: 1- عو امل نفسية تتعلق بشعور الأطفال بالقلق و عدم شعور هم بالأمن حيث أن

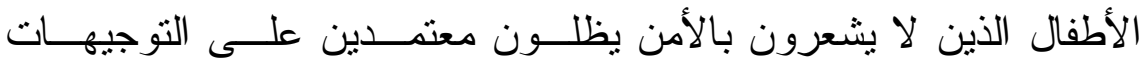

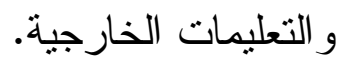


ץ- أحلام اليقظة بحيث لا يستطيع الطفل التركيز على ما يـدور حولــه فـي عـي غرفة الصف. r- تقلبد نموذج ضعف الانتباه كأن يكون الأب أو الأم أو الأثخاص القريبين

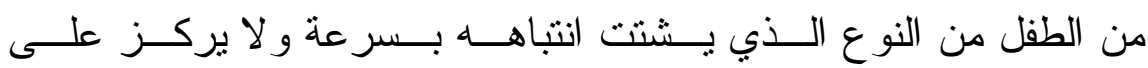
موضو عات محددة او مناسبة.

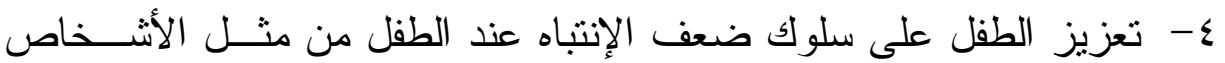

$$
\text { القريبين (الأم - الأب - المعلم ل... إلخ) }
$$

0- عو امل متعلقة بالمناخ الصفي غير المناسب متل كثرة المـشكلات داخــل الصف وخارجه، الوسائل التعليمية غير المناسبة، أسلوب التدريس وطبيعة

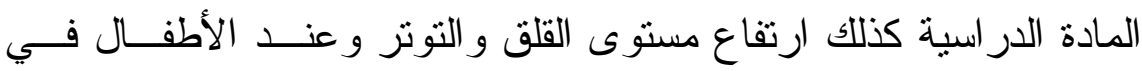
الصف. ا- - عدم الانجذاب و الميل للمادة العلمية التي يتم شرحها من قبل المعلم. فإن عدم القدرة على التركيز أو تثتت الإنتباه له أسبابه المتعددة ومظاهره

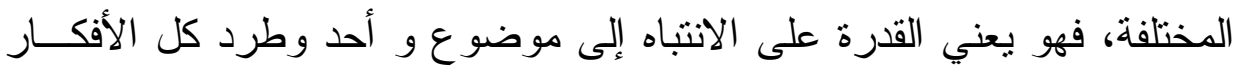

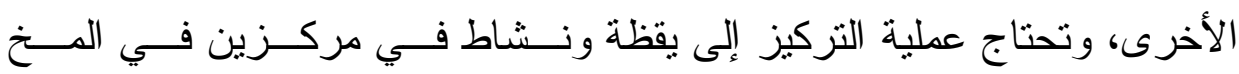

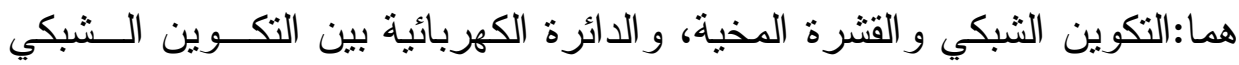

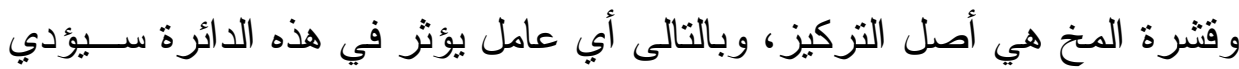

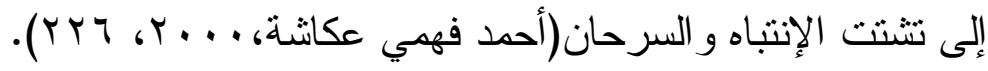

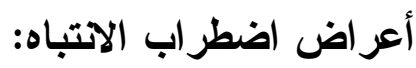
1- عدم الارتياح إذا ما جلس في مكان فهو لا يستقر على حالة واحدة و إنما يأخذ بعبث بكل ما هو متتاول بيديه. 
r- يثير انتباهه كل ما يحدث من حوله سو اء ادركه بـسمعه أو ببــصره أو

$$
\text { بأي حاسة من حو اسه. }
$$

ب- يجيب على الأسئلة قبل أن ينهي المعلم طرحه و غالباً ما تكـــون إجاباتــــ

$$
\text { خاطئة بسبب تسر عه. }
$$

ع- يجد صعوبة في متابعة ما يسمعة أو يقر أه.

0- عادة ينتقل من نشاط لآخر دون أن ينهي النشاط الأول .

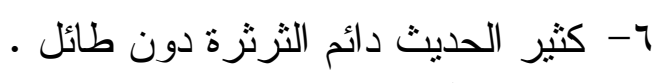

V يقاطع الآخرين وهم يتحدثون قبل أن يتمو ا كلامهم و غالباً ما يتدخل فيما

$$
\text { لا يعنيه. }
$$

$$
\text { 1- لا يعتبر لحديث وكلام الآخرين أي اهتمام. }
$$

9- غالباً ما تضيع منه أو ينسى أدو اته رغم أنه بحاجة الأبة إليها.

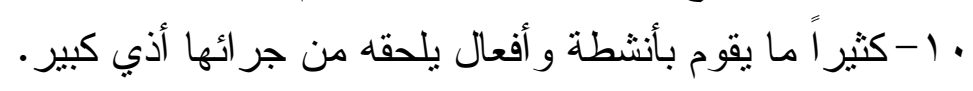

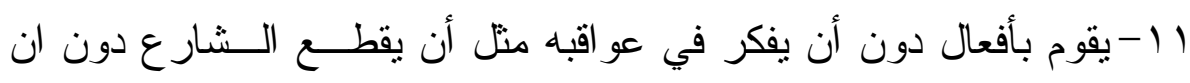

$$
\text { ينظر ليمينه و لا يساره. }
$$

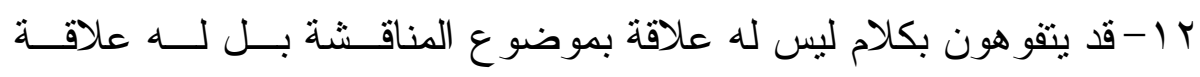

$$
\text { بالأفكار التي تدور في عقله. }
$$

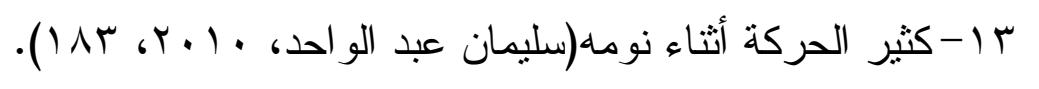

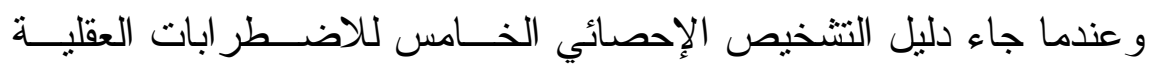

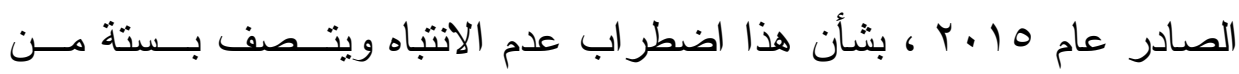

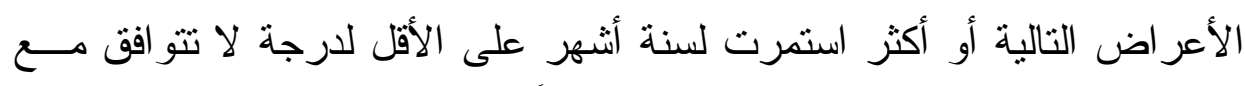

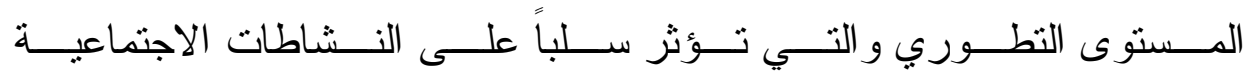
و المهنية/الأكاديمية.

r المجلد الرابع


إن الأعر اض ليست فقط مظهــر أ مــن مظــاهر الــسلوك الاعتر اضــي

و العدائية، أو الفتل في فهم المهام أو التعليمات بالنسبة للمر اهقين الاكبـر ســـناً و البالغين (سن V V وما فوق)، فيلزم خمسة أعر اض على الأقل.

ا- غالباً ما يخفق في اعارة الانتباه الدقيق للتفاصيل أو يرتكب أخطــاء دون مبالاة في الو اجبات المدرسية أو في العمل أو في النـشاطات الأخــرى (مثنلا إغفال أو تقويت التفاصيل، العمل غير الدقيق).

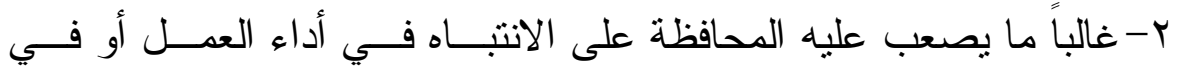

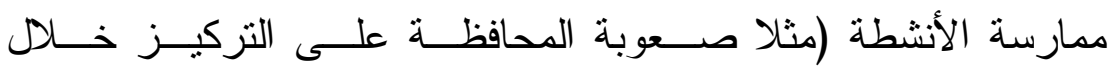
المحاضر ات، المحادثات أو القر اعة المطولة). ب- غالباً ما يبدو غير مصن عند توجيه الحديث إليه مباشرة (عقله يبدو فـي مكان آخر مثنال). ع- غالباً لا يتبع التعليمات ويخفق في إنهاء الواجب المدرسـي أو الأعمـــال

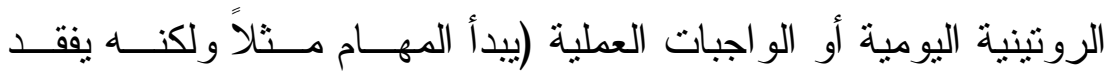
التزكيز بسر عة كما يتشتت بسهولة).

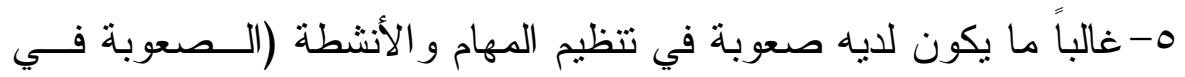

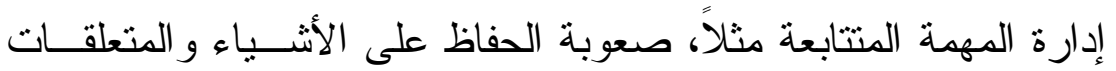

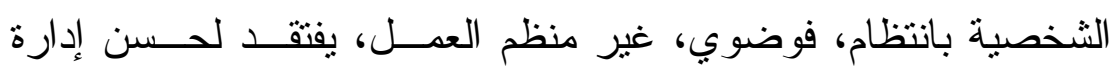
الوقت، و الفشنل بالإلتز ام بالمو اعيد المحددة). ج- غالباً ما يتجنب أو يكره أو يتردد في الانخر اط في مهام تتطلب منه جهداً

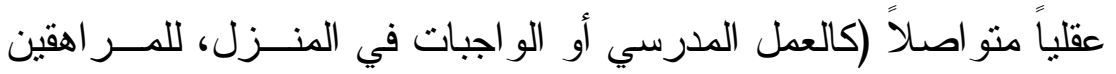

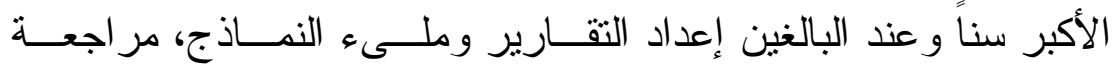

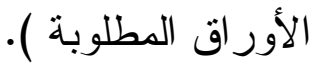


V- غالباً ما يضيع اعر اضاً ضرورية لممارسة مهامه وأنسشطته (كـالمو اد

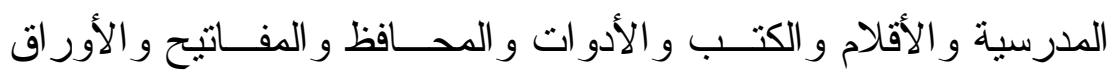

$$
\text { و النظار ات و الهو اتف النقالة). }
$$

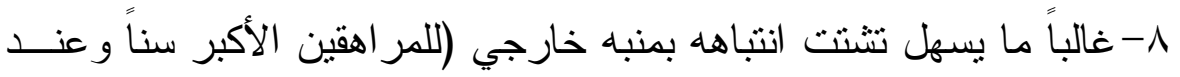

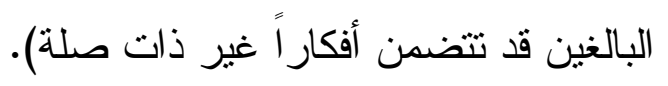

9-كثير النسيان في الأنشطة اليومية (مثل الأعمال الروتينية اليومية، إنجاز

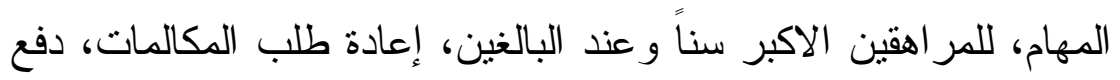

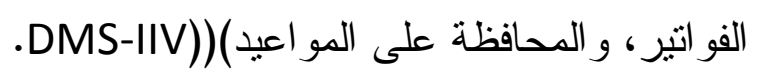

\section{هنالك ثلاث اضطر ابات تحدث للإنتباه :}

1- شرود الذهن: وهو الإزاحة المبانشرة و السريعة للإنتباه خلال سلسلة من

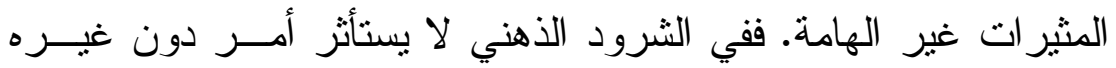

$$
\text { بيؤرة الثعور ، فهو حالة عدم مبالاة. }
$$

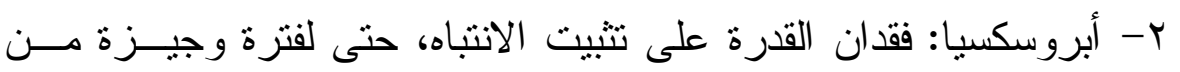

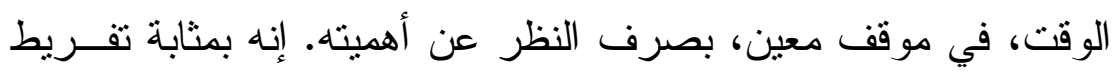

$$
\text { في الانتباه. }
$$

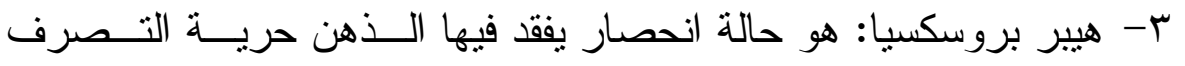

ويصبح أسير الوساوس المحيرة و الهو اجس المنسلطة والأفكار الثابتــة.

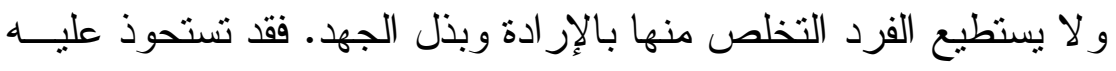

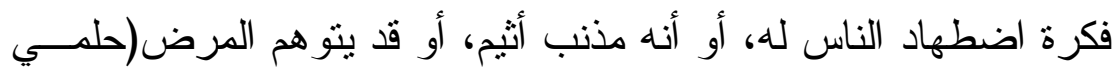

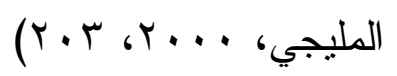

وقد يعتري الذهن فتور طارىء للحظات زمنية قصيرة نتيجة عو امل ذاتية

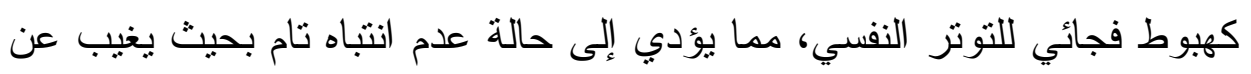

المجلد الرابع


الثعور موضوع الانتباه كلية كأنه غير موجود بالمرة فيقال أن المرء قد أصــابه "السهو". السهو هو ، حالة شبيهة بالغييوبة العارضة التي سر عان ما تزول.

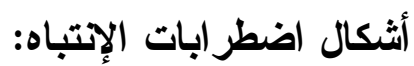

يمكن تحديد اضطر ابات الاتتباه في عدة مظاهر يعرض لها:

1- نقص الاتتباه: حيث يقل مدي الانتباه و لا يستطيع الطفل نركيـز انتباهــــ سوي لفتر ات محدودة من الوقت، كما يصعب عليه الاستمر ار في التركيز و الإنتباه سو اء كان ذللك في أثناء العمل أم اللعب.

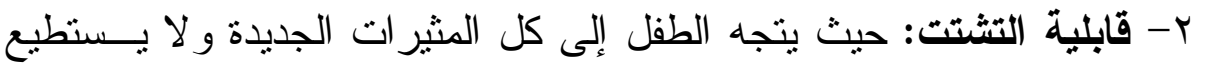

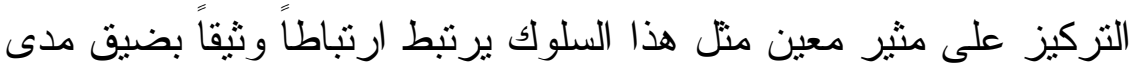

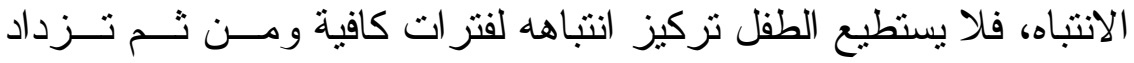
قابليته للتشتت.

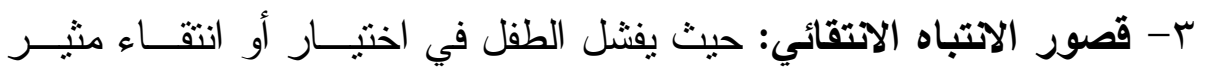

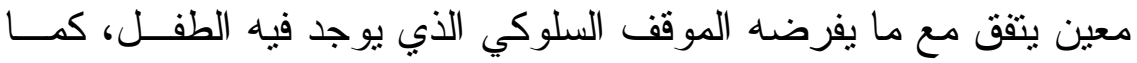
يفشل في تركيز انتباهه تجاه المثير ات المهمة.

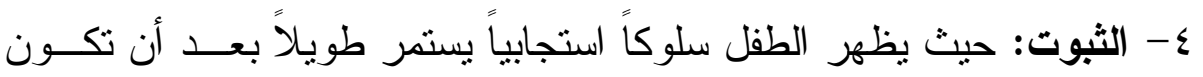

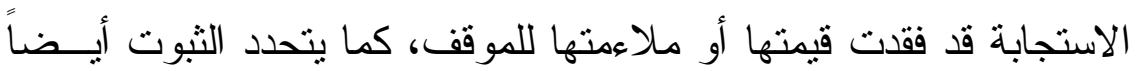

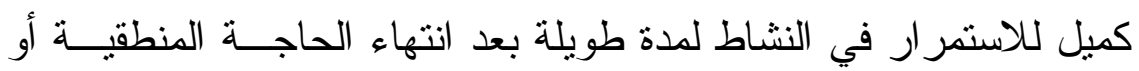
الهدف من القيام به، ويمكن ملاحظة سلوكيات الثبوت في الأنشطة التـي لئي يستمر فيها الطفل دون توقف حتى تصبح غير ملائمة للموقف.

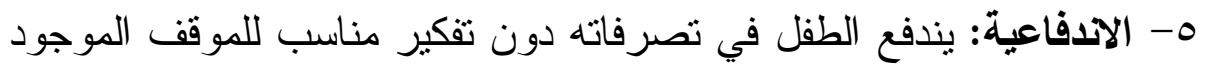

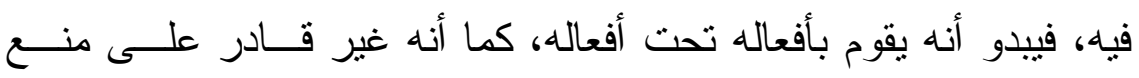

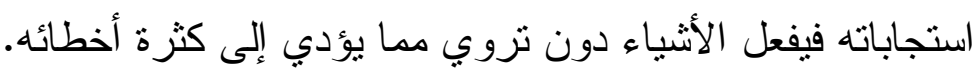


؟- فرط النشاط: حيث تزداد كمية الحركة و النشاط لدى الطفل بـــا يعـوق

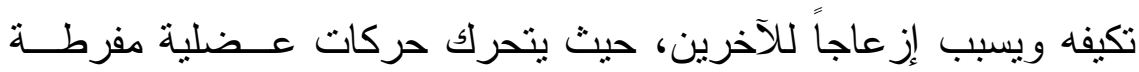

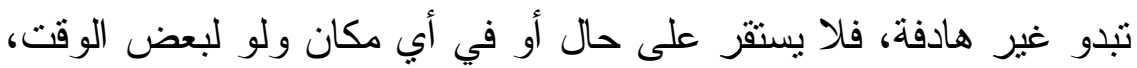

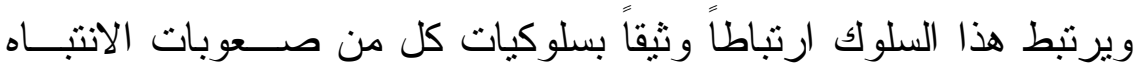

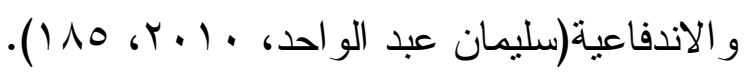

وهناك أيضاً العديد من الاعراض الثانوية لاضطراب الاتباه عند الأطفال:

$$
\begin{aligned}
& \text { 1- انخفاض التحصيل الدر اسي • }
\end{aligned}
$$

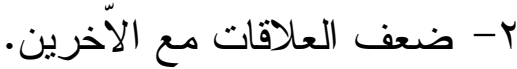

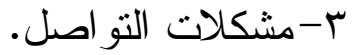

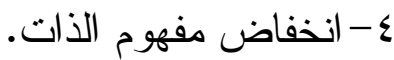

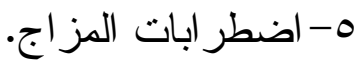

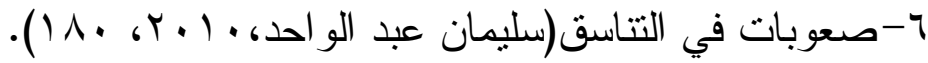




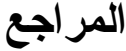

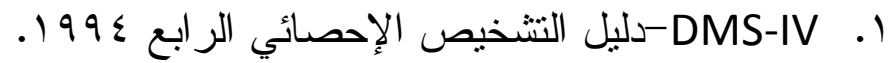

r. أحمد الدردير (د.ت). الثرح الكبير علي حاثية الاســوقي، دار إحيــاء

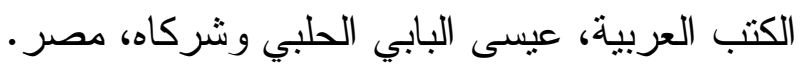

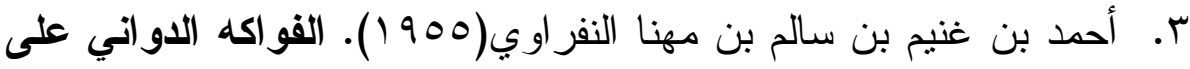

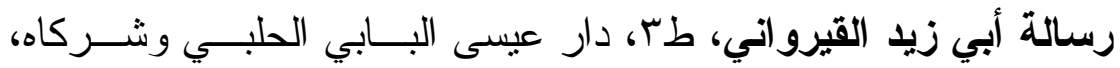

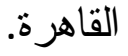

ع. أحمد عبد اللطيف أبو أسـعد (10 ـ ب). عــم الــفس الإرشــادي، دار

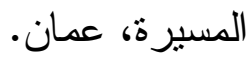

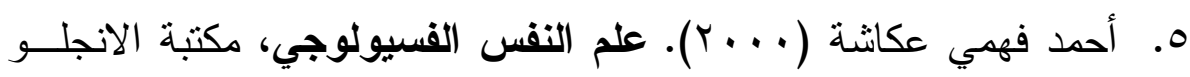

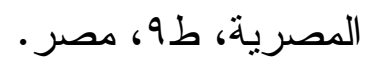

7. أحمد محمد مبارك الكندي (ب99 (19). علم النفس الاسري، مكتبة الفلاح،

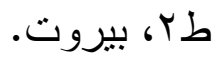

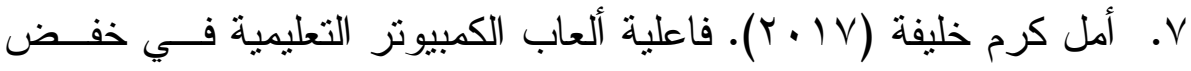

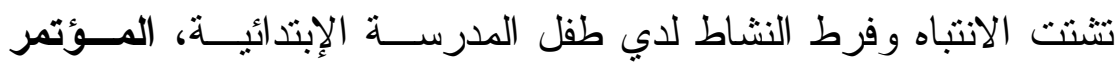

$$
\text { العلمي العربي الر ابع - الدولي الأول }
$$

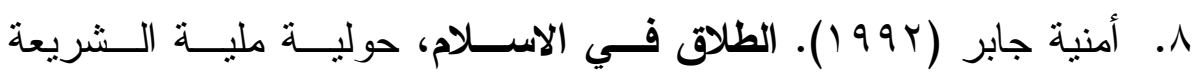

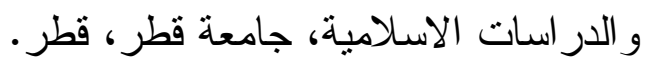




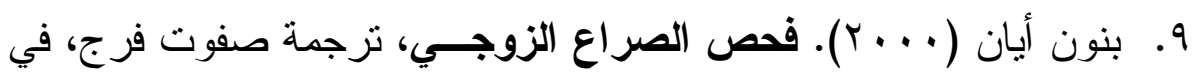

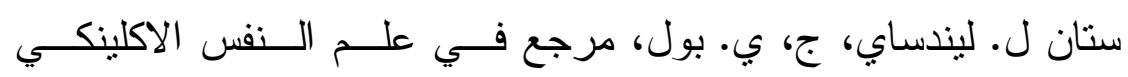

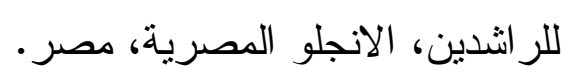

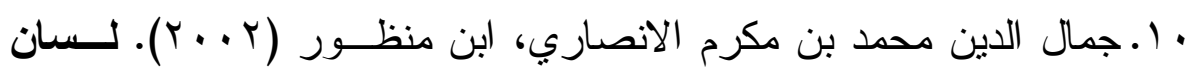

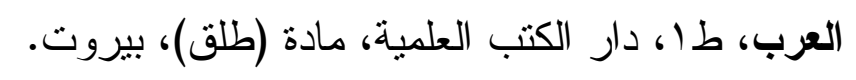

1) ا. حلمي المليجي (·191 ). علم نفس المعاصر، دار المعرفة الجامعيـة،

$$
\text { مصر. }
$$

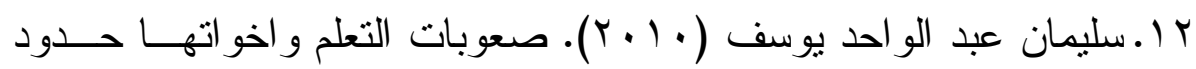

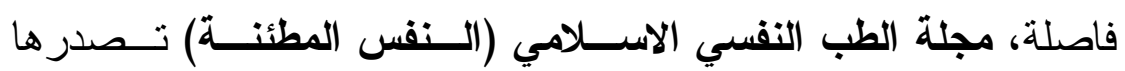

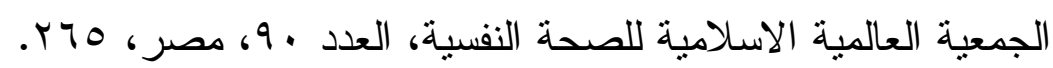

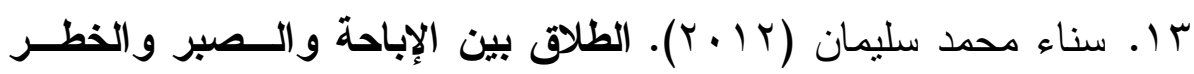

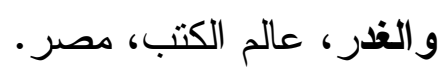

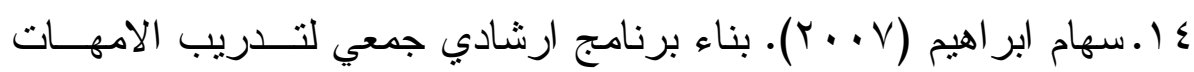

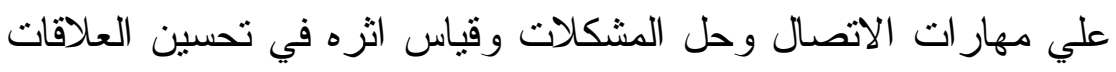

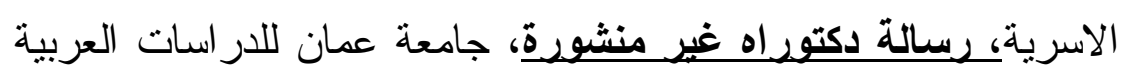
العليا، عمان. 10 ـ السيد حافظ (910 (19). فقة السنة، دار الكتاب العربي، طV، بيروت.

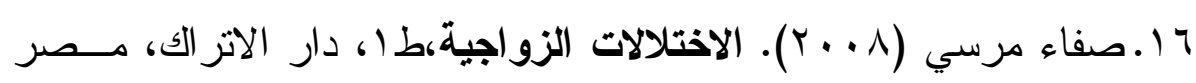

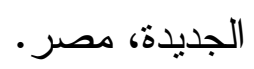
V V . عبد الحليم محمود السيد (.999). علم النفس عــام، مكتبــة غريــب، مصر 


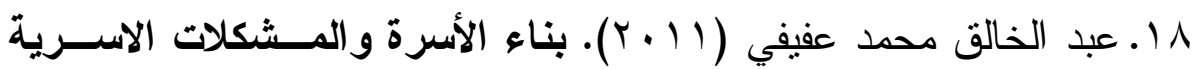
المعاصرة، المكتب الجامعي الحديث، الاسكندرية، مصر .

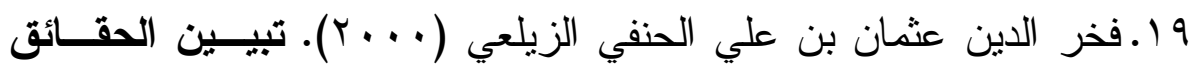

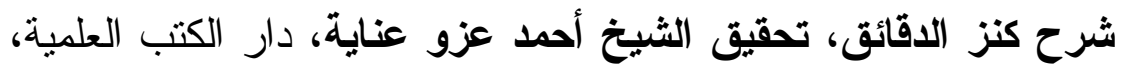

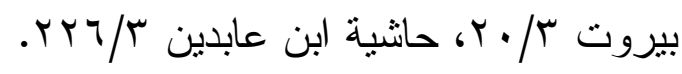
• r.قانون الأحو ال الثخصية 19091، 7.

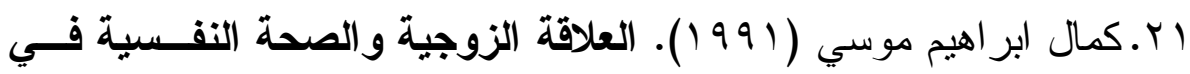
الاسلام وعلم النفس،، طا، دار القلم، الكويت.

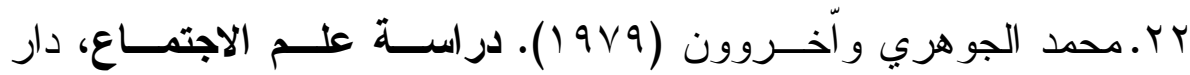

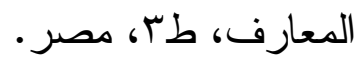

r r. محمد الخطيب الثربيني (د.ت). مغني المحتاج إلى معرفة معاني الفاظ

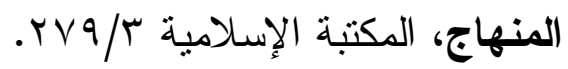

ع r. مصطفي بن العدوي (911 (1). احكام الطلاق في الثريعة الاسـلامية،

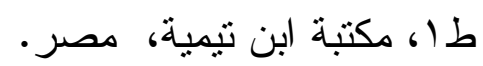

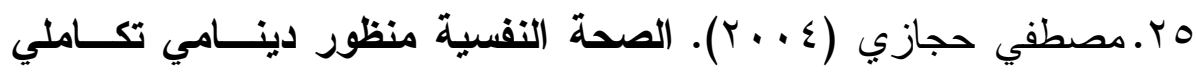

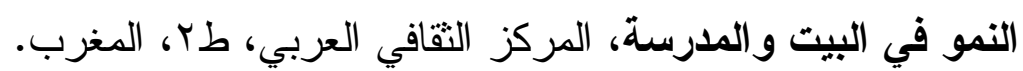

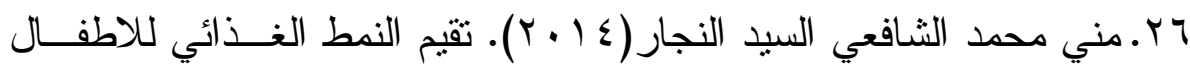

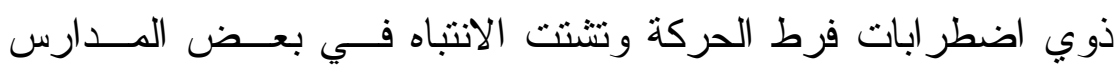

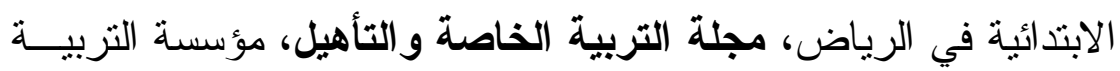

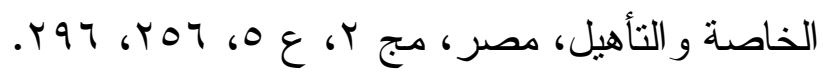


YV. موفق الدين محمد عبد الله و أحمد بن محمد ابن قدامه (997 ( )). المغني

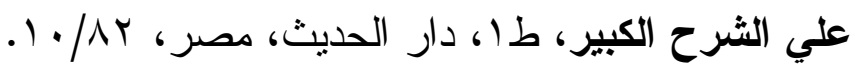

28. Carsini, R.(1999). Encyclopedia of psychology 'New York : willey Interrsence Publication.

29. Cordovan, J \& Jacobson, S (1993). Couple distress, In H.D.Barlow (Ed). Clinical handbook of psychological disorders, newyork. 